Portland State University

PDXScholar

$1-1-1986$

\title{
Effects of infection by dwarf mistletoe (Arceuthobium americanum) on the population dynamics of lodgepole pine (Pinus contorta)
}

James Leo Wanner

Portland State University

Follow this and additional works at: https://pdxscholar.library.pdx.edu/open_access_etds Let us know how access to this document benefits you.

Recommended Citation

Wanner, James Leo, "Effects of infection by dwarf mistletoe (Arceuthobium americanum) on the population dynamics of lodgepole pine (Pinus contorta)" (1986). Dissertations and Theses. Paper 518. https://doi.org/10.15760/etd.518

This Dissertation is brought to you for free and open access. It has been accepted for inclusion in Dissertations and Theses by an authorized administrator of PDXScholar. Please contact us if we can make this document more accessible: pdxscholar@pdx.edu. 


\title{
EFFECTS OF INFECTION BY DWARF MISTLETOE (Ârceuthobium americanum) ON THE POPULATION DYNAMICS OF LODGEPOLE PINE (Pinus contorta)
}

by

JAMES LEO WANNER

A dissertation submitted in partial fulfillment of the requirements for the degree of

\author{
DOCTOR OF PHILOSOPHY \\ in
}

ENVIRONMENTAL SCIENCES AND RESOURCES/BIOLOGY

Portland State University 
TO THE OFFICE OF GRADUATE STUDIES AND RESEARCH:

The members of the Committee approve the dissertation

of James Leo Wanner presented June 11, 1986.

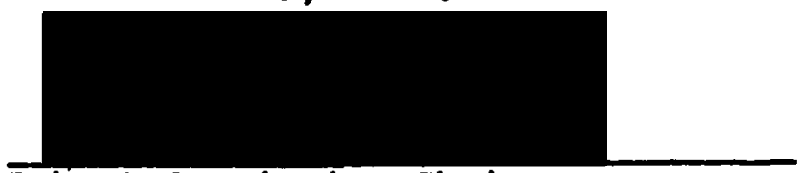

Robert 0. Tinnin, Chairman

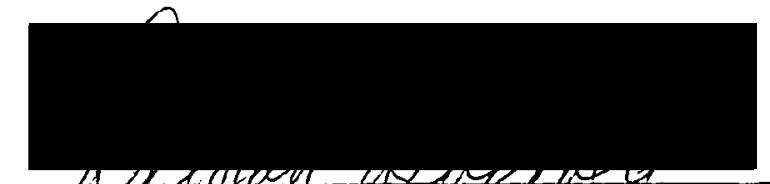

Deborah $\mathrm{A}$. Duffield

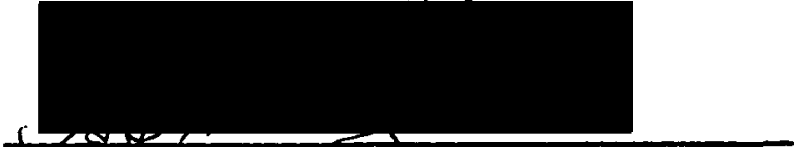

Gordon IIgour

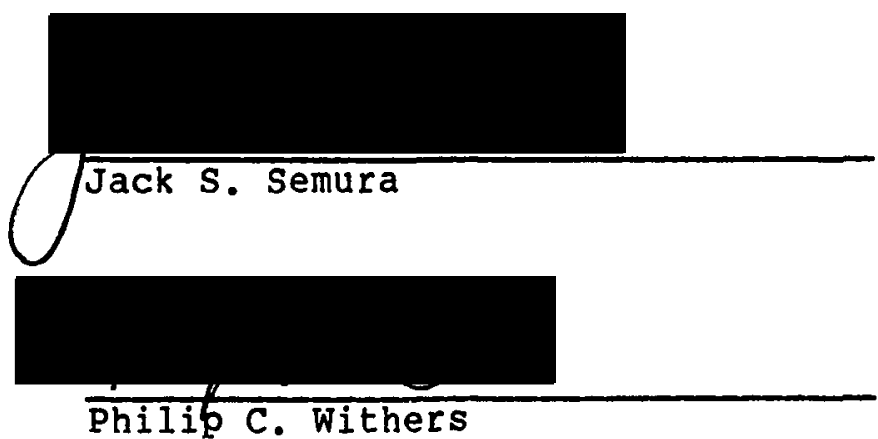

APPROVED :

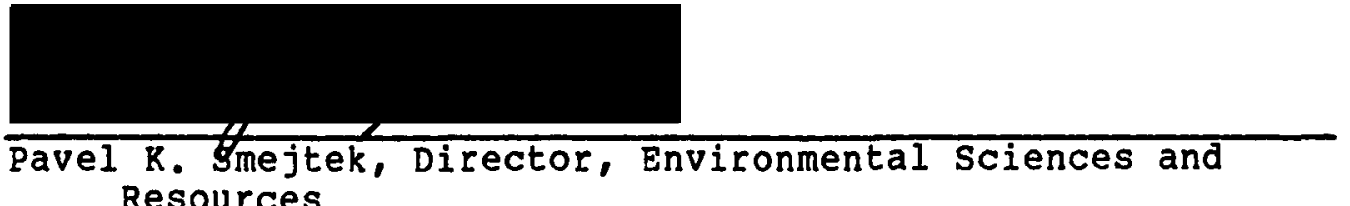
Resources

Bernard Rośs, Acting Dean of Graduate Studies and Research 
AN ABSTRACT OF THE DISSERTATION OF James Leo Wanner for the Doctor of Philosophy in Environmental Sciences and Resources: Biology presented June 11, 1986.

Title: Effects of Infection by Dwarf Mistletoe (Arceuthobium americanum) on tise Fopulation Dynamics of Lodgepole Pine (Pinus contorta).

APPROVED BY MEMBERS OF THE DISSERTATION COMMITTEE:
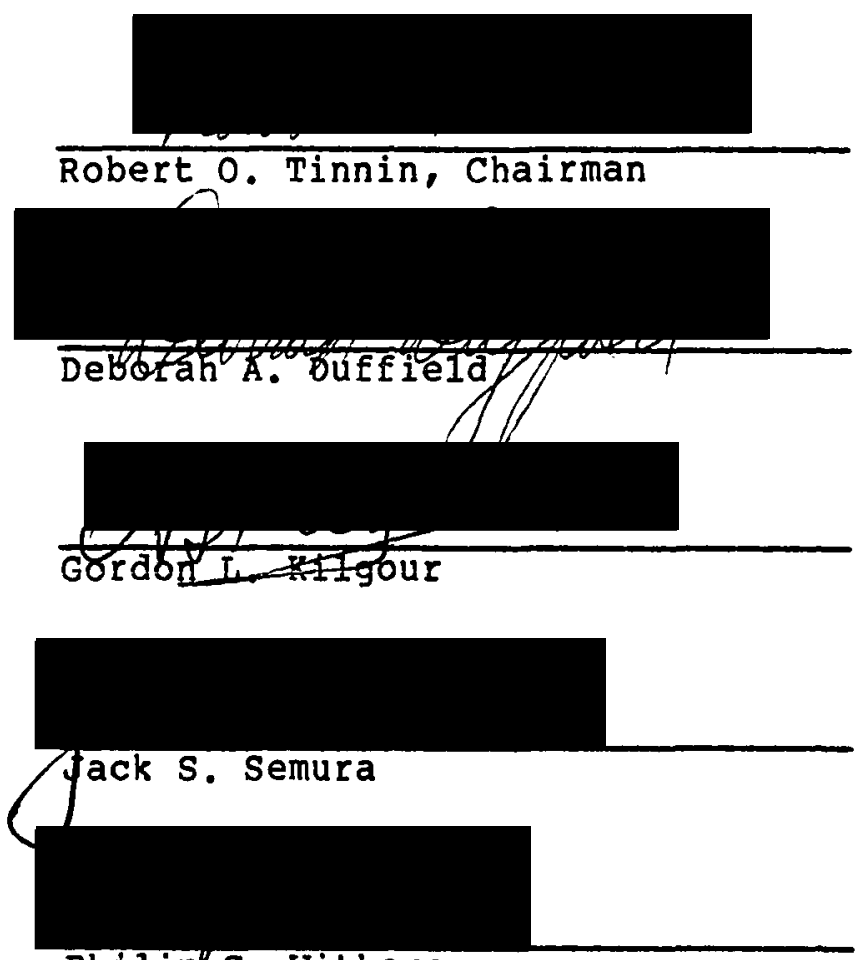

Philip Withers

Dwarf mistletoes are parasitic flowering plants that infect conifer tree species. They have many effects on 
their host including structural changes in branch formation, reduced wood quality, increased branch and tree mortality, and reduced growth and reproduction. The effects of Arceuthobium americanum on the seed crop of pinus contorta were examined over a two year period to evaluate the effects of altered host reproductive success on host population dynamics.

Heavily infected trees produced significantly fewer cones than uninfected trees during the first season in which cones were collected. Cone length, number of seeds per cone, individual seed mass, and total calories per seed were significantly reauced in moderately and heavily infected trees. Viability of seeds from infected trees was not reduced. Trees with different levels of infection showed trends consistent with the above but no significant differences were observed during the second season. A significant reduction in pollen production was observed in heavily infected stands during the one season this character was measured.

The diameter growth rate was similar between uninfected and heavily infected trees during the first season but significantly lower in heavily infected trees during the second season. Adequate growth and reproduction were not maintained simultaneously in heavily infected trees. This supports the hypothesis that available carbohydrate reserves are more limited for infected trees. 
The number of seeds that were produced, disseminated, and that germinated per square meter of forest floor was significantly less in heavily infected plots than in lightly infected plots. Survival of one year old seedlings was significantly higher in heavily infected plots. This increase in survival negates the effects of fewer germinated seeds in these same plots.

Significant increases in the abundance of woody litter due to increases in mortality of mature trees and witches brooms were positively correlated with increases in seedling survival in moderately and heavily infected stands. Woody litter may reduce the moisture stress of germinated seeds thereby contributing to successful seedling establishment. Seedling density was, therefore, determined by environmental factors, not by variation in seed density. There were 100 times more seeds produced than needed to support the observed seedling density.

Survival of trees less than 45 years of age also increased as the level of infection in plots increased. This increased the fraction of total density that seedlings and saplings represented in moderately and heavily infected stands. The total basal area of all plots were similar, regardless of level of infection, implying that the populations were resource limited. The dramatic differences in age distribution between lightly and heavily infected plots, however, indicate that resources are partitioned 
differently among seedlings, saplings, and mature trees in plots having different levels of infection. seedlings and saplings represented a greater proportion of the total basal area in heavily infected plots than in lightly infected plots. The soil environment was homogenous throughout the study site, therefore, I suggest that A. americanum causes the observed differences in resource partitioning between lightly and heavily infected stands.

Arceuthobium americanum affects primarily mature trees. Dominant host trees experienced higher mortality in heavily infected plots than in lightly infected plots. This reduces the total stand biomass composed of all mature trees. Reduced vigor of dominant trees also contributes to reductions in biomass in heavily infected stands. Increased mortality and reduced vigor of dominant host trees frees resources which reduces intraspecific competition thereby contributing to increased seedling and sapling survival in heavily infected plots. Consequently, stand density increases as the level of infection increases. One exception to the above explanation was observed. Reduced seed production directly affected the success that P. contorta invaded clear-cuts. The number of favorable sites for seedling establishment in cleared areas are initially in excess of the number of available seeds. Therefore, seedling density adjacent to heavily infected stands 
was significantly less than opposite lightly infected stands.

This study demonstrates that the negative short term efferts of parasitism are offset by long-term adjustments in host population dynamics thereby providing a stable community structure. Arceuthobium americanum promotes a disturbance regime that favors the regeneration of $\underline{p}$. contorta. This contributes to the perpetuation of the host which is essential for stable host-parasite coexistence. 


\section{ACKNOWLEDGMENTS}

I wish to thank Dr. Robert Tinnin for his advice and guidance during the collection and analysis of data and preparation of this dissertation. I also give thanks to the U.S. Forest service for their cooperation in setting aside permanent study plots at my study site.

I give special thanks to my wife for her patience and understanding. 
TABLE OF CONTENTS

PAGE

ACKNOWLEDGMENTS........................ i i

LIST OF TABLES......................... vii

LIST OF FIGURES .......................

INTRODUCTION........................... I

SECTION A

INTRODUCTION........................ 10

Materials and Methods................... 11

Description of site and Plots........... 11

Soil Characteristics................ 12

Soil Texture

Soil Profile and Root Penetration

Soil Fertility

Forest Floor Litter................. 14

Dominant Tree Canopy.................. 14

Species Composition................ 15

statistical Analysis............... 16

RESULTS........................... 17

Soil Characteristics............... 17

Soil Texture

Soil Profile and Root Penetration Soil Fertility

Forest Floor Litter................. 20

Dominant Tree Canopy................ 23

Species Composition................. 23 
PAGE

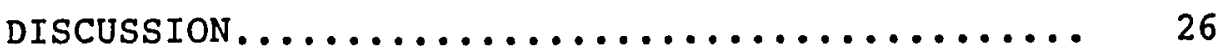

SECTION B

INTRODUCTION........................ 33

MATERIALS AND METHODS................. 34

Cone and seed Production.............. 34

Seed Viability, size, and caloric Content.. 35

Pollen Production................... 37

Host vigor..................... 38

Statistical Analysis................ 38

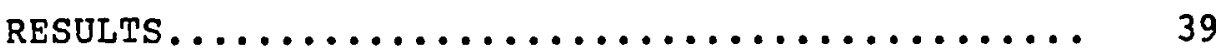

Cone and seed production.............. 39

seed Viability, size, and Caloric content.. 42

Pollen Production................... 45

Host vigor...................... 45

DISCUSSION......................... 50

SECTION C

INTRODUCTION............................ 55

MATERIALS AND METHODS.................. 56

Early Population Success.............. 56

Age structure................... 57

Regeneration in Clear-Cuts............ 59

Statistical Analysis................. 60

RESULTS............................ 61

Early Population Success.............. 61

Age structure..................... 61 
Regeneration in clear-Cuts........... 70

DISCUSSION......................... 74

Stand History................... 81

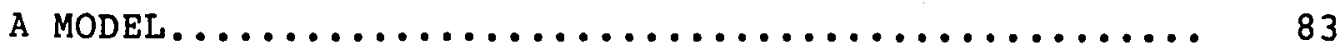

DISCUSSION............................... 90

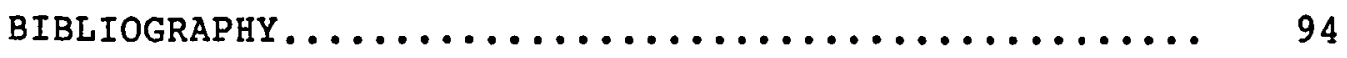

APPENDIX A............................... 102

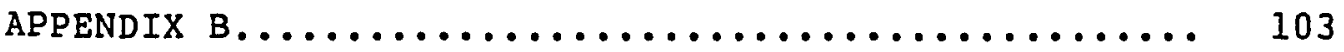


I a. Mean Values with Standard Errors for the of Gravel Fraction (Particles)

$2 \mathrm{~mm}$ dia.) and of sand Fraction (Particles

( $2 \mathrm{~mm}$ dia.) in Air Dried Soil Samples

(depth $25 \mathrm{~cm}$ ) from one-Hectare Plots

Having Different Levels of Infection.

b. Mean Values with Standard Errors

for the Percent clay, Silt, and sand

in the Sand Fraction of Soil samples

from Plots having Different Levels of

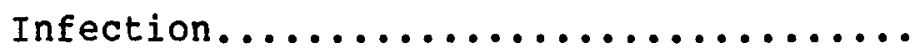

II Mean Values with standard Errors for

Mineral and organic Content, $\mathrm{pH}$, and

Cation Exchange capacity of Soils

(depth $25 \mathrm{~cm}$ ) from one-Hectare Plots

with Different Levels of Infection.......

II Mean Sample Results with Standard Errors

for Logs or Limbs Intersected per $5 \mathrm{~m}$

Transect Within Plots supporting

Different Levels of Infection.......... 
viii

TABLE

PAGE

IV Mean Values with Standard Errors for Density (no./30 $\mathrm{m}$ transect) and Coverage ( $\mathrm{m} / 30 \mathrm{~m}$ transect) for Pursha tridentata.. 24

$V$ Mean Values with Standard Errors for Coverage $\left(\mathrm{m}^{2} / \mathrm{m}^{2}\right)$ for Annual and Minor Perennial Plant species Within Plots Having Different Levels of

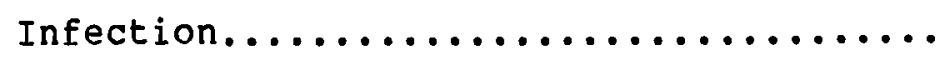

VI Mean Sample Results with standard Errors for Cone and seed Production in 1983 and 1984 for Trees with Different Levels

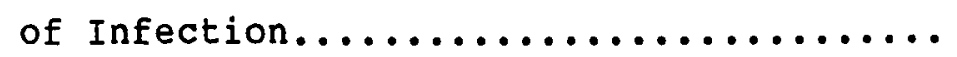

VII Mean Sample Results with Standard Errors for Cones Collected in 1983 and 1984 from Trees with Different Levels of

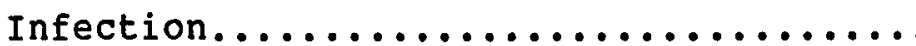

VIII Mean Sample Results with standard Errors for seeds collected in 1983 and 1984 from Trees with Different Levels of Infection.....................

IX Mean Sample Results with standard Errors for Caloric Content of seeds collected in 1983 and 1984 from Trees with Different Levels of Infection................. 4 
$\mathrm{X}$ Mean Values with standard Errors for the Percentage of Pollen Deposited Within Lightly, Moderately, and Heavily Infected plots at Specific Periods during Pollen Release in $1984 \ldots \ldots \ldots \ldots .46$

XI Mean Values with standard Errors for Pollen Production in 1984 within oneHectare Plots having Different Levels of Infection....................

XII Mean Sample Results with Standard Errors for D.B.H. (cm), Age (yrs.), Bole Volume $\left(m^{3}\right)$, and Height $(m)$ for Trees with Different Levels of Infection..........

XIII Mean Values with standard Errors for Diameter Growth Rate (mm/yr.) in 1983 and 1984 for Uninfected and Heavily

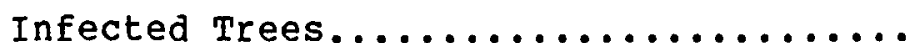

XIV Mean Sample Results with standard Errors for Host Seed Production During 1983 and 1984 Within Lightly and Heavily Infected Plots.................... 62

XV Mean Sample Results with Standard Errors for Germlings Within Plots having Different Levels of Infection between

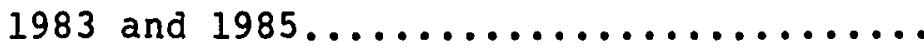


XVI Mean Sample Results with standard Errors

for First Year seedlings in 1984 and

1985 Within Plots Having Different

Levels of Infection.................. 64

XVII Mean Sample Results with standard Errors

for Age Classes from plots with

Different Levels of Infection.......... 65

XVIII Ratio of the Number of Individuals per 100

$\mathrm{m}^{2}$ in Heavily Infected to Lightly

Infected Plots for Each Age class....... 67

XIX Total Number of Individuals and Total

Basal Area (sq. m) per One-half

Hectare in Plots with Different

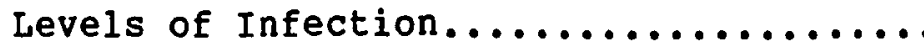

XX Mean Values with Standard Errors for

Density within Plots having Different

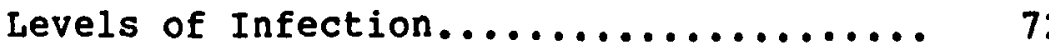

XXI Mean Values with Standard Errors for

D.B.H. of Dominant Trees in Plots with

Different Levels of Infection...........

XXII a. Matrices for Lightly Infected stands.

b. Matrices for Heavily Infected Stands.... 
1. Regression Lines of D.B.H. (cm) as a Function of Age (yrs.) with 958

Confidence Limits for Trees within

Lightly and Heavily Infected one-

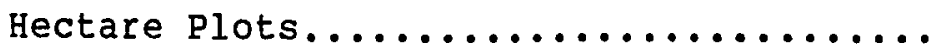

2. Age Distribution for Stands with

Different Levels of Infection. The

Percent Representation by Each Age

Class Greater than 6 Years of Age.......

3. Natural Log of the total Basal Area per

One-Half Hectare Represented by

Individuals at each Increment of

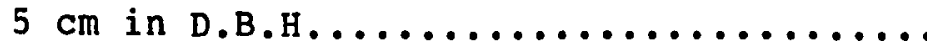

4. Mean Number of Saplings per Square Meter

with Standard Errors in Clear-Cuts

Opposite Lodgepole Stands with Light

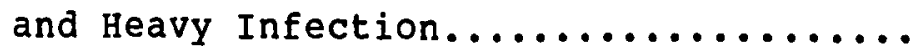

5. Mean Number of Germlings per Square Meter

with Standard Errors in clear-cuts

Opposite Lodgepole stands with Light

Heavy Infection.................. 
xii

F IGURE

PAGE

6. Schematic Representation for the

Replacement of Dominant Trees by

Subordinate Age Classes after 908

Directed Mortality in Dominant Trees..... 


\section{INTRODUCTION}

Population biologists have rarely studied parasites and pathogens as part of natural ecosystems (Burdon, 1982). They tend to think of disease principally in terms of epidemics that suddenly arise, sweep through a host population and then disappear. The literature contains many accounts of such pheonomena within both plant and animal populations (Dinoor, 1984; Anderson, 1979). The concept of an epidemic, however, may give rise to a false impression of the interaction between host and parasite populations. Examination of long-term studies on host-parasite associations reveals patterns of stable co-existence in both plant and animal populations (Browning, 1974; Burdon, 1982; Edmonds, 1974; Smith, 1973; Riordon, 1977). In natural communities parasites are likely, therefore, to play a complementary role to that of predators in regulating host populations (Anderson, 1978; Begon, 1981; May, 1978). The regulatory potential of parasites is realized through direct efFects on host survival and reproduction, increased susceptibility to predation, and reduced competititve fitness (Anderson, 1979; Lanciani, 1975; May, 1981; Schmidt, 1978).

Plant responses to parasites vary depending upon the type of parasite. Many plant parasites, e.g., insects, nematodes, fungi, and bacteria invade their host and 
inflict harm by damaging host tissue. This can result in the immediate death of the individual (Agrios, 1978). Parasitic flowering plants, on the other hand, develop an association with the conductive tissues of their host, from which they derive water, minerals, and organic nutrients (Kuijt, 1969). The host, consequently, is not killed directly but subjected to considerable physiological stress which can lead to its predisposition to other pathogens and drought (Calder, 1983). Reduced growth and reproduction are generally induced by: (1) utilization of host nutrients, both organic and inorganic; (2) accelerated water loss; (3) reduction of stored carbohydrates in host; (4) unbalanced and altered patterns of nutrient flow between crowns and roots of host plants; and, (5) disturbed, hormone-mediated processes which adversely affect normal bud and shoot development (Knutson, 1979, 1983).

Reductions in crop yield due to infection by parasitic flowering plants can be very large. Knutson (1979, 1983) cites a number of cases. In Yugoslavia, orobanche (broomrape) reduced sunflower seed yields by 338 ; and striga (witchweed) reduced Sorgum yield by 40 to 70 percent. The leafy mistletoes are very damaging in Europe where they cause reductions in growth up to 258 in infected conifer trees. In England, crop yields of apple trees have been reduced by 40 z when infected with Viscum album. Citrus trees in the Philippines inflected with Loranthus langsome have 
fewer and smaller leaves and premature fruit fall. In Malaya, kapok trees sustain heavy branch mortality and are often completely killed when parasitized by Dendrophthoe pentandrua or Viscum articulatum. Many shade and ornamental trees are severaly deformed or killed by phoradendron species in the Arkansas River Valley (U.S.A.). Arceuthobium causes an estimated annual loss of 20 million cubic meters of wood fiber in North America and in parts of Europe and Asia (Hawksworth, 1973).

Knutson (1979) stated, "One aspect of parasitism of trees by mistletoes and other parasitic angiosperms goes beyond disease and suggests an ecosystem function". He proposed that, "the purpose [of parasitism] is to provide ecosystem level stability at the cost of individual tree damage". For example, Alexander and Hawksworth (1975) reported that branches infected with dwarf mistletoe (brooms) tend to break more frequently than uninfected branches and accumulate near the host, which increases the probability of fire. A burn initiates a renewed succession of seral plant species (Krebs, 1985). Tinnin et al. (1982) suggested that the renewal of seral stages (of which the host is a part) contributes to stable coexistence between host and parasite.

A major consequence of infection by mistletoes is reduced host reproduction (Calder, 1983; Gill, 1953; Kuijt, 1969). Reduced seed-crops can effect present and future 
population dynamics of the host, and thereby the community as a whole (Harper, 1977). This is especially true for plant species that rely entirely upon seeds for their regeneration, such as annuals and most gymnosperm species (Cook, 1980). However, there are also environmental factors which affect the number of host seedlings establishments by defining the number of areas (safe-sites) which favor seed germination and survival.

The florest floor environment surrounding seeds can become modified whithin infected stands. For example, two general host responses to infection by mistletoe which can lead to changes in the accumulation of forest litter are die back of infected limbs and increased tree mortality (Knutson, 1983; Kuijt, 1969). These symptoms augment 1itter deposition onto the forest floor, which can affect the number of safe-sites, and consequently the number of seedling establishments.

Dwarf mistletoes are parasitic flowering plants that form long-term associations with conifer tree species (Knutson, 1979; Hawksworth, 1972). By reducing host vigor it reduces host seed production and life expectancy (Boyce, 1961; Fowel1s, 1956; Hawksworth, 1972; Kuijt, 1955; Pierce, 1960). However, the consequences of these reductions on the population structure of the host species are not well understood. It is essential to study the production, germination, and subsequent establishement of seeds of host 
populations in the field, under both healthy and infected conditions, to better understand the effect of dwarf mistletoes on the population dynamics of their host.

Much is known about the general aspects of forest tree population biology (Begon, 1981; Harper, 1970, 1977; Silvertown, 1982; Solbrig, 1980; West, 1981; White, 1970, 1974). Consider a bare area of soil onto which a rain of seeds of a single species is falling. The seeds landing are dormant or non-dormant depending on the species, although seeds from most conifer tree species do not remain viable more than a year in the soil (Cook, 1980; Kellman, 1977). Not all of the seeds landing on the bare area will land in sites suitable for germination. The soil surface therefore operates as a sieve, determining what fraction of the incoming seed rain germinates to produce young plants (Grime, 1979; Grubb, 1977; Harper, 1970). Temperature, water economy, depth of soil, and periodicity of light are important environmental variables determining seed germination. The nature and selectivity of the sieve can be altered by the presence of growing vegetation which affects seed germination.

A process of self-thinning, largely governed by the amount of intraspecific competition, is an important step in the life cycle of a plant population. Harper (1970) demonstrated that within natural populations, increasing mean mass of surviving individuals more than compensates 
for decreased density, and the total mass of the population increases. The environment under these conditions is more effectively utilized. The total yield per unit area increases with decreasing density (Westoby, 1981, 1984) until the trend is limited by attainment of the genetically defined size limits of the individual plants in question, or by attainment of the carrying capacity of the site.

Burdon and shattock (1980) developed a model which focuses attention on the effects of parasites on particular stages in the life cycle of a plant population. They recognized four general phases in a standard life cycle:

1. the reserve of dormant seeds in the soil;

2. germination and recruitment of seedlings;

3. the mature plant; and,

4. mature seed prior to dispersal.

Infection of the population by a pathogen or parasite at any of these phases affects future population size; however, the effect may vary. Air-borne pathogens have little direct effect during phase 1 and 2 , while the impact of soil-borne pathogens is maximal during the germination-seed recruitment phases. This generally results in immediate death of the attacked individual, thereby reducing the number of individuals and, thus, the intensity of intraspecific competition. Damage caused during the mature plant. phase (3) rarely kills the plant directly, but, due to reduced vigor, reduces the number and/or size of seeds 
produced which limits the number of viable individuals entering the next generation.

Dwarf mistletoe, air-borne in its dispersal, has its greatest development on mature conifers and is rarely responsible for killing its host directly. Rather, it predisposes its host to other pathogens and drought (Hawksworth, 1972). According to Burdon and Shattock's model it can be expected that the size of future populations of the host are affected as a result of reductions in number and/ or size of seeds.

Schaffer et al. (1983) found that the number of seeds produced by Pinus contorta var. latifolia Engelm, (Rocky Mountain lodgepole pine) does not vary significantly with the level of dwarf mistletoe infection. However, their data represented the seed production of only one season, and does not assess the consequential effects of infection on the annual variability of host seed production.

I have examined the effect of Arceuthobium americanum Nutt and Engelm, (dwarf mistletoe) on the seed crop of Pinus contorta var. murrayana Grev. and Balf, (sierra Nevada and Cascade lodgepole pine) over a two year period, as well as the consegeunces of observed effects on future populations. The finished work is presented in three sections. The first section introduces the reader to the physical and biotic environment in which the lodgepole pine seedlings were examined. Section two summarizes the 
observed effects of infection by dwarf mistletoe on host cone and seed production, and on host vigor. Section three reviews the consequences of altered host reproduction on two features of lodgepole population dynamics: (1) the ability of the population to maintain its current size, and (2) the ability of the population to invade clearings or expand its distribution. Following these three sections is a summary of the entire project and the implications of the findings for host-parasite coexistence. 


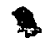

SECTION A

HABITAT DESCRIPTION 
INTRODUCTION

Arceuthobium research can contribute to the understanding of stable coexistence between host and parasite populations as manifested by reports of this parasite's long-term coexistence with various conifer hosts (Hawksworth, 1972; Knutson, 1979; Scharpf, 1982), including pinus contorta (Wass, 1976; Baranyay, 1970; Alexander, 1966). I chose Pinus contorta var. murrayana for study for two reasons. 1. It occurs in monospecific stands over very large areas. This structural simplicity of the community facilitates accurate observation of host-parasite interactions and reduces the overall complexity of the study. By observing monospecific stands, certain variables, such as interspecific competition with other conifers for light, nutrients, and space, are of no significance. Consequently, attention can be focused on the effects of infection on the population dynamics of the host.

2. Mature lodgepole pine trees are small compared to other species of pine (Fowells, 1965). This facilitates the collection of many types of data, particularly that pertaining to cone and seed production. By comparing stands of the lodgepole pine that support different levels of dwarf mistletoe infection the effects 
of reduced seed production upon the population dynamics of the host may be assessed. Although the effect of dwarf mistletoe on the host seed population is the major consideration of this study, other biological and physical components of the environment also contribute to seed and seedling success by influencing the number of favorable sites available for establishment. Characteristics of the soil (nutrient and moisture retention), forest floor litter (protection), dominant tree canopy (light), and species composition (competition) are among the important parameters in determining the number and quality of these sites (Cook, 1980; Grubb, 1977; Roberts, 1981). An area suitable for comparison of stands with different levels of dwarf mistletoe infection required, therefore, a high level of homogeneity in topography and soil characteristics for accurate data interpretation of the effects due to dwarf mistletoe.

MATERIALS AND METHODS

Description of Site and Plots

I located a study site approximately 3.2 kilometers southeast of Crescent Lake, Oregon, at an elevation 1,425 meters. The site supports, over its whole area, a mature stand of one tree species, Pinus contorta var. murrayana, with a patchy distribution of Arceuthobium americanum superimposed over the study area. The topography is almost flat 
and the study area encompasses approximately 2.5 square kilometers.

I established twenty one-hectare plots in 1983. Five were estimated to be lightly infected, five moderately infected, and ten heavily infected. The estimates of the infection levels were based on the dwarf mistletoe rating system developed by Hawksworth (1977). Trees having a diameter at breast height $(d . b . h$.$) greater than 14.5 \mathrm{~cm}$ were rated in each of ten randomly placed, $100 \mathrm{~m}^{2}$ subplots within each one-hectare plot. The estimates were obtained for each plot by averaging the measured infection ratings of the trees in the ten subplots.

\section{Soil Characteristics}

Soil texture. I examined homogeneity of the soil texture among the one-hectare plots using Brower and zar's (1984) method. For each sample, soil was collected to a depth of $25 \mathrm{~cm}$ with an oakfield soil coring tool at one randomly selected point within each plot. The sample was air dried and then sifted through a \#10 sieve (pore size 2.0 $\mathrm{mm}$ ) to separate the gravel and sand fractions. The sand fraction was oven dried, then thoroughly mixed in one liter of $5 \%$ calgon solution and allowed to settle. The weight (in grams) of soil particles still in suspension after given time intervals over an eight hour period was obtained with an RSTM soil hydrometer (152H). 
The percent soil in suspension at each time interval was calculated. The diameter of the largest particle in suspension was estimated at the time of each hydrometer reading using the formula:

$$
\mathrm{d}=\mathrm{c} / \mathrm{t}
$$

where $d$ is the particle diameter, $t$ is the settling time (in minutes), and $\mathrm{c}$ is a constant. The constant varied with the weight of soil still in suspension (soil hydrometer reading) and the values were obtained from a standardized table (Brower and zar, 1984). I obtained a portrait of soil texture by plotting the percent soil in solution (ordinate) against the $\log$ of the largest particle still in suspension (abscissa).

Soil profile and root penetration. At a centrally located site in lightly and heavily infected one-hectare plots, I dug a hole one or two decimeters beyond the point of deepest root penetration. Three measurements were made: depth of the "A" horizon (for top soil), depth of the " $B$ " horizon (one layer under top soil), and the depth of the deepest root penetration. Each horizon was easily identified by distinctive color bands of soil particles. The "A" horizon was brown and was measured from the bottom of the ground litter. The "A" horizon was red and was measured from the bottom of the "A" horizon. The depth of the deepest penetrating roots was measured from the top of the "A" horizon. 
Soil fertility. I collected soil samples from each of the ten random points within each one-hectare plot. At each point, I removed plant litter from the surface and collected approximately $50 \mathrm{~g}$ of soil to a depth of $25 \mathrm{~cm}$. The 10 subsamples from each one-hectare plot were mixed and a sample of the mixture sent to the oregon State University Soil Testing Laboratory for the analysis of: $\mathrm{P}, \mathrm{K}, \mathrm{Ca}, \mathrm{Mg}$, and $\mathrm{N}$ (essential macronutrients for plant growth). The organic matter, $\mathrm{pH}$, and cation exchange capacity of the soil samples were also determined.

\section{Forest Floor Litter}

I estimated the density and coverage of woody litter within each one-hectare plot using a $5 \mathrm{~m}$ linear transect (Brower, 1984). Each transect extended northward from each of ten random points within each of the one-hectare plots, and was examined for its intersection with logs (downed trees) and limbs. If the transect fell by chance along the length of a $\log$, I extended the transect westward rather than northward. The fraction of the $5 \mathrm{~m}$ transect intersected by logs and/or limbs was used to determine litter coverage. The number of intersections was used to determine litter density.

\section{Dominant Tree Canopy}

Gaps in the dominant tree canopy affect the establishment of lodgepole pine (West, 1981). I used estimates of 
density and distribution of lodgepole trees with d.b.h. greater than $14.5 \mathrm{~cm}$ (the dominant canopy trees in lodgepole stands) to compare the availability of gaps among the onehectare plots. I recorded the number of dominant trees in ten random, $100 \mathrm{~m}^{2}$ subplots within each one-hectare plot.

\section{Species Composition}

I sampled the plant species present in the understory using a plot technique for annuals and a linear transect for major perennials other than lodgepole pine (Brower, 1984). Purshia tridentata Pursh. (antelope bush) was the only other major perennial at the site. At ten random locations in each of the 20 one-hectare plots, three parallel $10 \mathrm{~m}$ transects (each ten meters apart) were used to sample coverage (intersection) by $\underline{P}$. tridentata. I used coverage values for individual plants to determine density.

I sampled ten random $0.5 \mathrm{~m}^{2}$ plots in each of the 20 one-hectare plots for coverage by annual species. A coverage rating was assigned to each species depending on the approximate fraction of the $0.5 \mathrm{~m}^{2}$ plot occupied: 0 , if it was not present; 1 , if it was present and occupied up to $0.03 \mathrm{~m}^{2}$ ( 68 of the area); 2, if it occupied between 0.03 and $0.125 \mathrm{~m}^{2}(6-258$ of the area); 3 , if it occupied between 0.125 and $0.25 \mathrm{~m}^{2}(25-508$ of the area); and 4 , if it occupied between 0.25 and $0.5 \mathrm{~m}^{2}$ (50-1008 of the 
area). The coverage by an inäividual species within each one-hectare plot was obtained by averaging its coverage at ten random locations. The total coverage for all annual species within each one-hectare plot was determined by summing the mean coverage of all individual species (Barber, $1980)$.

Statistical Analysis

I used One-WAY ANOVA and SCHEFFE's test for unequal sample size to test the variation among plots with different levels of infection. Data tested involved:

1. Percent gravel, sand, silt, and clay in soil;

2. Soil $\mathrm{pH}$ and cation exchange capacity;

3. Nutrient content of soil;

4. Depth $(\mathrm{cm})$ of the soil horizons and deepest penetrating roots;

5. Number and coverage $(\mathrm{cm})$ of logs and limbs on the forest floor:

6. Density of lodgepole trees with a.b.h. greater than $14.5 \mathrm{~cm}$;

7. Coverage $(\mathrm{cm})$ by Purshia tridentata; and, 8. Coverage $\left(\mathrm{m}^{2}\right)$ by annuals and minor perennials. Percentage data were transformed to arcsines before being subjected to statistical analysis (Sokal and Rohlf, 1969). The distribution of trees with d.b.h. greater than $14.5 \mathrm{~cm}$ 
was determined by CHI-SQUARE GOODNESS OF FIT (Kershaw, 1973).

RESULTS

Soil Characteristics

Soil texture. The mean percent gravel fraction (particles $>2 \mathrm{~mm}$ dia.) and sand fraction (particles < $2 \mathrm{~mm}$ dia.) in air dried soil samples from plots with different levels of infection were uniform (Table I). The percent clay, silt, and sand of the sand fraction was also not correlated with the level of infection in plots (Table I). According to a standardized table for soil texture (Brower and zar, 1984) the soil has a loamy sand texture. Soil profile and root penetration. The depth of soil horizons and the deepest penetrating roots were similar in lightly and heavily infected plots. Depth of the "A" horizon was 5.3 and $6.4 \mathrm{~cm}$ in lightly and heavily infected plots respectively. Depth of the " $B$ " horizon was 34.2 and $34.3 \mathrm{~cm}$ respectively. The depth of the deepest penetrating roots was 63.3 and $62.6 \mathrm{~cm}$ in lightly and heavily infected plots respectively.

Soil fertility. The mineral content and cation exchange capacity of the soil did not indicate a trend correlated with the level of infection within plots, although heavily infected plots had significantly higher levels of calcium (Table II). Both the percent organic matter and 
A. MEAN VALUES WITH STANDARD ERRORS FOR THE \& GRAVEL FRACTION (PARTICLES > 2MM DIA.) AND \& SAND FRACTION (PARTICLES < 2MM DIA.) IN AIR DRIED SOIL SAMPLES (DEPTH 25CM) FROM ONE-HECTARE PLOTS HAVING DIFFERENT LEVELS OF INFECTION. B. MEAN VALUES WITH STANDARD ERRORS FOR THE PERCENT CLAY, SILT, AND SAND IN THE SAND

FRACTION OF SOIL SAMPLES FROM PLOTS

HAVING DIFFERENT LEVELS OF INFECTION

a.

\& Gravel Fraction

Infection Level

Light $(n=5)$

Medium $(n=5)$

Heavy (n - 10)

(> $2 \mathrm{~mm}$ dia,

$14 \pm 1.14^{a}$

$18 \pm 1.99^{a}$

$17 \pm 1.40^{\mathrm{a}}$
8 Sand Fraction $(<2 \mathrm{~mm}$ dia. $)$

$86 \pm 1.14^{a}$

$81 \pm 1.99^{a}$

$28 \pm 1.40^{\mathrm{a}}$

b.

Infection Level $\$$ Clay

8 Sand

Light
$(n=5)$
$0.02 \pm 0.01^{a}$
$12.18 \pm 0.53^{a b}$
$87.80 \pm 0.55^{a b}$

Medium

$(n=5)$

$0.03 \pm 0.01^{a}$

$13.90 \pm 0.82^{b}$

$86.00 \pm 0.73^{b}$

Heavy
$(n=10) 0.01 \pm 0.01^{a}$
$11.85 \pm 0.43^{\mathrm{a}}$
$88.20 \pm 0.43^{a}$

\footnotetext{
${ }^{1}$ Within a column pertaining to a particular measurement, any pair of mean values that do not have at least one common letter are significantly different, $(p<0.05)$.
} 
TABLE II

\section{MEAN VALUES WITH STANDARD ERRORS FOR MINERAL AND ORGANIC CONTENT, PH, AND CATION EXCHANGE CAPACITY OR SOILS (DEPTH $25 \mathrm{CM}$ ) FROM ONE- HECTARE PLOTS WITH DIFFERENT LEVELS OF INEECTION ${ }^{1}$}

\begin{tabular}{|c|c|c|c|}
\hline & \multicolumn{3}{|c|}{ INEECTION LEVEL } \\
\hline & Light $(n=5)$ & Medium $(n=5)$ & Heavy $(n=5)$ \\
\hline p (ppm) & $10.00 \pm 0.35^{a}$ & $8.80 \pm 0.82^{a}$ & $10.00 \pm 0.50^{\mathrm{a}}$ \\
\hline$R(\mathrm{ppm})$ & $60.80 \pm 5.16^{a}$ & $54.80 \pm 2.25^{a}$ & $64.60 \pm 5.04^{a}$ \\
\hline $\mathrm{Ca}(\mathrm{meg} / 100 \mathrm{~g})$ & $1.14 \pm 0.08^{a}$ & $1.16 \pm 0.08^{a}$ & $1.52 \pm 0.11^{b}$ \\
\hline $\mathrm{Mg}(\mathrm{meg} / 100 \mathrm{~g})$ & $0.19 \pm 0.01^{a}$ & $0.19 \pm 0.01^{a}$ & $0.22 \pm .02^{\mathrm{a}}$ \\
\hline Total Nitrogen ( $\$$ ) & $0.04 \pm 0.004^{a}$ & $0.04 \pm 0.0^{a}$ & $0.05 \pm 0.002^{a}$ \\
\hline Organic Matter (8) & $3.89 \pm 0.36^{a}$ & $4.71 \pm 0.13^{b}$ & $5.00 \pm 0.23^{b}$ \\
\hline $\begin{array}{l}\text { Cation Exchange } \\
\text { Capacity (meg/100 g) }\end{array}$ & $7.68 \pm 0.41^{\mathrm{a}}$ & $7.20 \pm 0.41^{a}$ & $8.26 \pm 1.03^{a}$ \\
\hline $\mathrm{pH}$ & $6.18 \pm 0.02^{a}$ & $6.14 \pm 0.03^{a}$ & $6.06 \pm 0.03^{b}$ \\
\hline
\end{tabular}

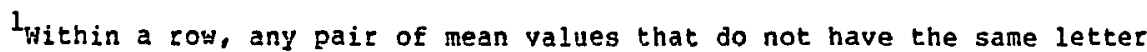
in common are significantly different, $(p<0.05)$. 
soil $\mathrm{pH}$ were correlated with the degree of infection within plots (Table II).

Forest Floor Litter

Analysis of the number and coverage of logs indicated that forest floor litter increases with the level infection within plots. The mean number of logs encountered within a $5 \mathrm{~m}$ transect in moderately and heavily infected plots was significantly higher than in lightly infected plots (Table III). The accumulated distance (in $\mathrm{cm}$ ) of $\log$ surface that the $5 \mathrm{~m}$ transect passed over (coverage) was also significantly higher in moderately and heavily infected plots (Table III). The percentage of times that one or more logs was encountered by a $5 \mathrm{~m}$ transect (frequency) indicates that the chance for intersection increased with the level of infection (Table III).

The mean diameter of logs encountered by the $5 \mathrm{~m}$ transect decreased as the level of infection within the plot increased (Table III). Age is directly related to d.b.h. as illustrated by fitted regression lines (Figure 1) for lightly and heavily infected plots at the study site (detailed statistical data are in Appendix A). Trees with d.b.h. of $10.9 \mathrm{~cm}$ (ave. log size on floor) in heavily infected stands are on on the average 61 years old and trees with d.b.h. of $15.6 \mathrm{~cm}$ (ave. log size on floor) in lightly infected stands are on the average 75 years old. This 
TABLE III

MEAN SAMPLE RESULTS WITH STANDARD ERRORS FOR LOGS OR LIMBS

INTERSECTED PER 5 M TRANSECT WITHIN PLOTS, SUPPORTING

DIFFERENT LEVELS OF INEECTIONS

\begin{tabular}{|c|c|c|c|c|c|}
\hline & $\begin{array}{c}\text { Infection } \\
\text { Level }\end{array}$ & $\begin{array}{c}\text { Number of } \\
\text {. Intersections } \\
(\text { no. } / 5 \mathrm{~m})\end{array}$ & $\begin{array}{c}\text { Coverage } \\
(\mathrm{cm} / 5 \mathrm{~m})\end{array}$ & Frequency & $\begin{array}{r}\text { Diameter } \\
(\mathrm{cm})\end{array}$ \\
\hline & Light & $\begin{aligned} 0.74^{a} & \pm 0.15 \\
n & 50^{15}\end{aligned}$ & $\begin{array}{c}11.54^{a} \pm 2.28 \\
n=50\end{array}$ & $\begin{aligned} 0.48^{a} & \pm 0.15 \\
n & =5\end{aligned}$ & ${ }_{n}^{15.60^{a}} \stackrel{ \pm 2.63}{=}$ \\
\hline \multirow[t]{3}{*}{ LOGS } & Medium & $\begin{aligned} 2.28^{b} & \pm 0.23 \\
n & =50^{23}\end{aligned}$ & $\begin{aligned} 25.36^{b} & \pm 3.41 \\
n & =50\end{aligned}$ & $0.7 \ddot{8}_{n}^{b} \pm 0.07$ & $11.32^{b} \pm \frac{0.62}{5}$ \\
\hline & Heavy & $\begin{array}{c}2.87^{b} \pm 0.23 \\
n=100^{0.23}\end{array}$ & $\begin{array}{c}31.16^{b} \pm 2.54 \\
n=100\end{array}$ & $\begin{aligned} 0.86^{b} & \pm 0.03 \\
n & =10^{0}\end{aligned}$ & $\begin{aligned} 10.93^{b} & \pm 0.67 \\
n & \equiv 10\end{aligned}$ \\
\hline & Light & $\begin{aligned} 1.06^{a} & \equiv 0.21 \\
n & =50\end{aligned}$ & ${ }_{n}^{3.38^{a}} \pm{ }_{50}^{0.64}$ & $0.46^{a} \pm 0.09$ & $\begin{aligned} 3.13^{a} & \pm 0.50 \\
n & =5\end{aligned}$ \\
\hline IIMBS & Medium & $\begin{aligned} 1.36^{a} & \pm 0.18 \\
n & =50\end{aligned}$ & $\begin{aligned} 4.16^{a} & \pm 0.64 \\
& =50\end{aligned}$ & $0.68^{b} \pm=0.02$ & $2.93^{a} \pm 0.23$ \\
\hline & Heavy & $\begin{aligned} 2.18^{b} & \pm 0.19 \\
n & =100^{-19}\end{aligned}$ & $\begin{array}{c}6.83^{b} \\
n\end{array}= \pm 10.86$ & $0.80^{b} \pm 0.01$ & $3.12^{a} \pm 0.14$ \\
\hline
\end{tabular}

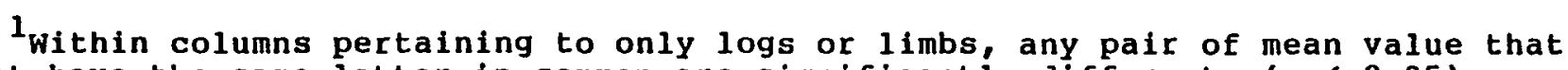
do not have the same letter in common are significantiy different, (p<0.05). 


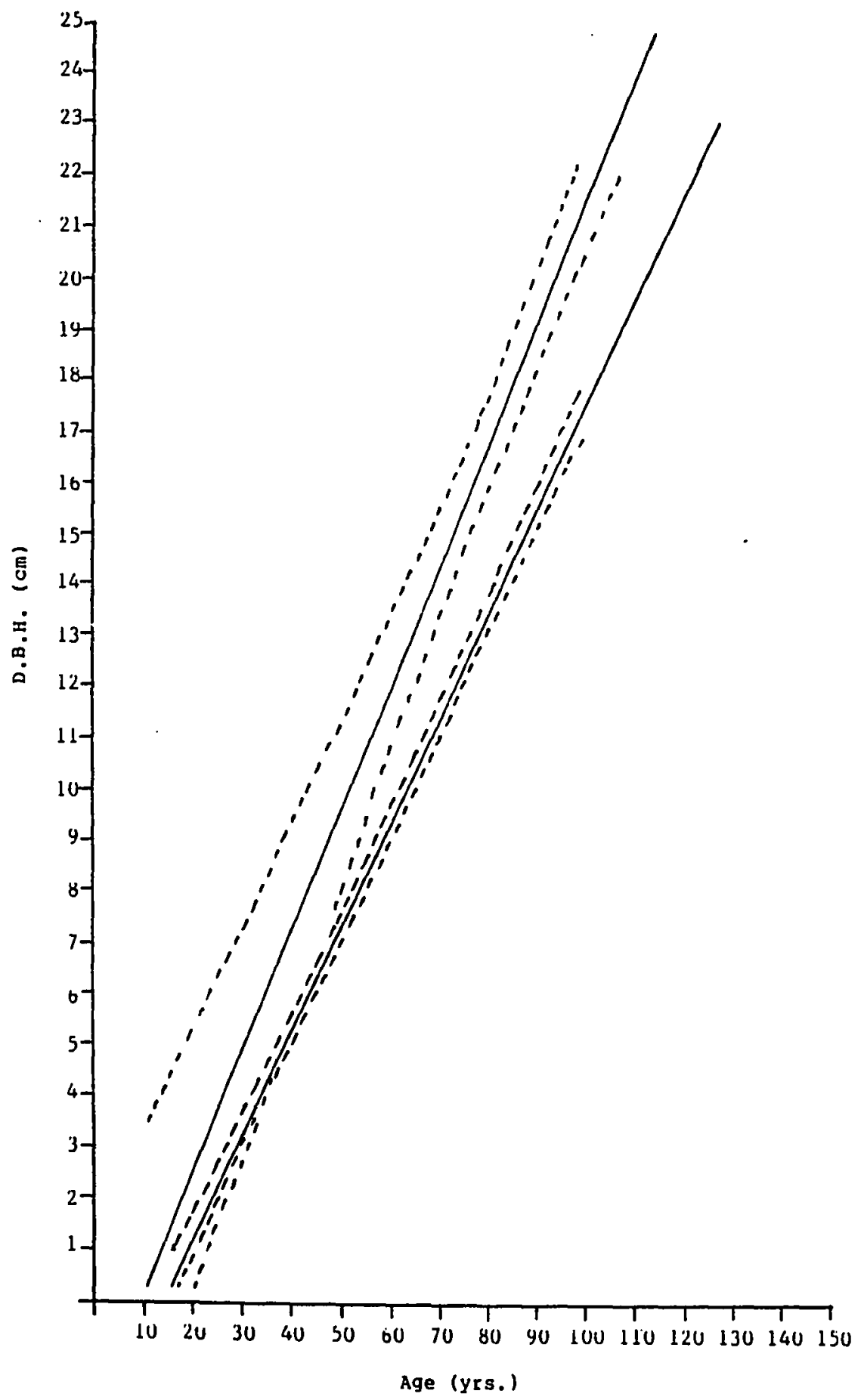

Eigure 1. Regression lines of d,b,h. $(\mathrm{cm})$ as a function of age (ycs.) with 958 confidence limits for trees within lightly and heavily infected one-hectare plots (detailed statistical data in Appendix $A$ ). 
suggests that trees die about ten years younger in heavily infected stands than in lightly infected stands.

A significant increase in the mean number of limbs intersected per $5 \mathrm{~m}$ transect occurred only in heavily infected plots, although data indicated a consistent increase with the level of infection (Table III). A significant increase in the mean values for the amount of limb surface intersected $(\mathrm{cm})$ per $5 \mathrm{~m}$ transect (coverage) occurred only in heavily infected plots (Table III). There was no significant difference in the mean diameter of 1 imbs related to the level of plot infection.

\section{Dominant Tree Canopy}

The density of dominant canopy trees (d.b.h. > 14.5

cm) was uniform: $4.02,4.72$, and 4.73 per $100 \mathrm{~m}^{2}$ in lightly, moderately, and heavily infected plots respectively. These trees were randomly distributed in all plots as determined by CHI-SQUARE GOODNESS OF FIT (Kershaw, $1973)$.

Species Composition

Density and coverage of the major shrub species, Pursha tridentata, were similar among plots with different levels of infection (Table IV). Similarly, little difference in the coverage of annuals (and other minor perennials) was apparent among any of the plots (Table V). 
TABLE IV

MEAN VALUES WITH STANDARD ERRORS FOR DENSITY (NO./30M TRANSECT) AND COVERAGE ( $M / 30 \mathrm{M}$ TRANSECT) FOR PURSHA TRIDENTATA WITHIN PLOTS HAVING DIFFERENT LEVELS OF INFECTION

\begin{tabular}{llc} 
Infection Level & $\begin{array}{c}\text { Density } \\
(\mathrm{no} / 30 \mathrm{~m})\end{array}$ & $\begin{array}{c}\text { Coverage } \\
(\mathrm{m} / 30 \mathrm{~m})\end{array}$ \\
\hline Light $(\mathrm{n}=50)$ & $3.18 \pm 0.21$ & $2.61 \pm 0.25$ \\
Medium $(\mathrm{n}=50)$ & $3.88 \pm 0.29$ & $3.36 \pm 0.34$ \\
Heavy $(\mathrm{n}=100)$ & $3.64 \pm 0.20$ & $3.24 \pm 0.23$ \\
\hline
\end{tabular}

${ }^{1}$ Any pair of mean values within a column are not significantly different, $(p<0.05)$. 


\section{TABLE V}

MEAN VALUES WITH STANDARD ERRORS FOR COVERAGE $\left(\mathrm{m}^{2} / \mathrm{m}^{2}\right)$ FOR ANNUAL AND MINOR PERENNIAL PLANT SPECIES WITHIN PLOTS HAVING DIFFERENT LEVELS OF INFECTION ${ }^{1}$

\begin{tabular}{|c|c|c|c|}
\hline Species & $\begin{array}{c}\text { Light } \\
(n=50)\end{array}$ & $\begin{array}{c}\text { Ifection Leve } \\
\text { Medium } \\
(n=50) \\
\end{array}$ & $\begin{array}{c}\text { Heavy } \\
(n=100)\end{array}$ \\
\hline \multicolumn{4}{|l|}{ Stipa } \\
\hline$\frac{\text { occidentalis }}{\text { var. californica }}$ & $0.14 \pm 0.01$ & $0.12 \pm 0.02$ & $0.15 \pm 0.03$ \\
\hline \multicolumn{4}{|l|}{ Eriogonum } \\
\hline chrysops & $0.01 \pm 0.01$ & 0 & $0.01 \pm 0.01$ \\
\hline \multicolumn{4}{|l|}{ Eriogomum } \\
\hline Viola purpurea & 0 & $0.01 \pm 0.01$ & $0.03 \pm 0.02$ \\
\hline \multicolumn{4}{|l|}{ Fragaria } \\
\hline chiloensis & 0 & 0 & 0.48 \\
\hline Lupinus lepidus & 0 & 0 & 0.72 \\
\hline \multicolumn{4}{|l|}{ Clarkia } \\
\hline rhomboidea & 0 & 0 & 0.72 \\
\hline TOTAL & $0.16 \pm 0.01$ & $0.14 \pm 0.02$ & $0.25 \pm 0.04$ \\
\hline
\end{tabular}

${ }^{1}$ Any pair of mean values within a row are not significantly different, $(p<0.05)$. 


\section{DISCUSSION}

Characteristics of the soil litter, dominant tree canopy, and species composition are interwoven and define the microenvironment in which lodgepole trees must become established. Their analysis was a prerequisite to the investigation of the effects that infection by dwarf mistletoe has on host seed production and any consequential effects on the development of lodgepole stands.

Soil is an important factor determining the availability of safe-sites for pine seedling establishment and survival (Grubb, 1977). The availability of moisture in the soil is largely determined by soil texture (spurr, 1964). Analysis of soil texture revealed high uniformity in all of the plots. This implies a uniformity of all properties associated with functional surface area of the soil volume. Among the most important of these would be the implied similarity of moisture retention because summer drought occurs annually in central oregon. Since the depth of soil horizons and the deepest penetrating roots were uniform throughout the study site, I assumed that soil restrictions on root development are also similar among all plots.

The uniform cation exchange capacity of soils suggests that the observed increase of calcium in heavily infected plots was due to factors other than strict physical 
properties of the soil. Two processes that may be more directly responsible are: 1) more rapid recycling of nutrients, which retards the leaching of minerals from the upper layers of the soil (Krebs, 1985), and 2) decay of more organic debris, which can lead to accumulation of minerals in the soil.

Soil $\mathrm{pH}$ varied inversely with increased level of infection within plots. Two factors contribute to this relationship. First, a higher accumulation of conifer needles in heavily infected plots can result in lower $\mathrm{pH}$ levels because conifer needles are acidic (Spurr, 1964). Second, fungal decay of greater amounts of organic material in heavily infected plots can increase production of organic acids (West, 1981). The organic content of soils was directly correlated with the level of infection. This suggests that the presence of dwarf mistletoe augments the rate of litter fall from trees.

The abundance of woody litter was directly correlated with the level of infection within plots. Significant increases in the number of significantly smaller logs in moderately and heavily infected plots indicate higher mortality among younger trees. The significant increase in limb litter in heavily infected plots reflects the higher incidence of witches' brooms.

Witches' Brooms occur in response to infection by $\underline{A}$. americanum and are usually associated with systemic 
infections. The occurrence of witches' brooms increases with the level of infection (Hawksworth, 1961). The brooms take form as a result of abnormal branching yielding a larger number of twigs within a given branch volume (Tinnin and Knutson, 1980). These broomed branches are more likely to be detached from the host during storms as a consequence of their increased weight and surface area.

The microenvironment surrounding logs and limbs contributes to successful establishment of lodgepole seedlings. A major cause of mortality among germinated seeds is moisture stress (Cook, 1980). Partial shading at the edges of logs and limbs slows down evaporative loss of soil moisture. Larger amounts of water may also accumulate in soils at the edges of logs as a result of run-off. The log itself imbibes water and (through slow evaporative water loss and blockage of wind) the local relative humidity can $r$ ise, thereby slowing seedling transpiration. Concealment from certain types of predators, e.g., small mammals. birds, deer, and elk, also contributes to seedling success. The abundance of woody litter can, therefore, substantially affect seedling establishment.

Gaps in the dominant tree canopy affect the establishment of shade intolerant species such as lodgepole pine (West, 1981). Uniform density and distribution of lodgepole trees (d.b.h. $>14.5 \mathrm{~cm}$ ) among plots implies uniformity of gaps in the dominant tree canopy throughout the 
study site. The presence of other species can also affect the availability of light. The only major perennial at the site, other than lodgepole pine, was pursha tridentata and its uniform density and coverage suggests that its impact upon lodgepole development is similar in all plots. Uniform coverage by annual species suggests also that interspecific competition between lodgepole and other plant species is consistent throughout the study site.

Two conclusions are drawn from the uniformity of species composition. First, any differences in lodgepole pine development among one-hectare plots with different levels of infection are probably not due to differences in interspecific competition or soil characteristics. Second, since no apparent developmental advantage or disadvantage is given to other species (other than lodgepole pine) any physical changes of the site due to dwarf mistletoe infection (i.e., forest litter) may be directed toward host survival.

Correlated with an increase in the level of infection were decreased soil pH, increased soil organic matter, and increased woody litter. Any or all of the these in combination may enhance the probability of seedling establishment by increasing the number of safe-sites, thereby offsetting any reduction in host seed production.

The safe-site concept refers to the set of habitat conditions that favor both germination and seedling survival 
(Cook, 1980). Safe-sites are complex environmental parameters composed of both physical and biotic factors that vary continuously. The number of seedlings can be limited by the number of safe-sites in a habitat. The problem with the safe-site concept is that, like the niche of a species, it is very hard to identify the safe-sites in a habitat prior to the appearance of seedlings. Consequently, it is difficult to determine whether fluctuations in seedling number are due to changes in seed production or abundance of safe-sites.

Dispersal to safe-sites is an important part of the regeneration phase during development of plant populations (Grubb, 1977; Harper, 1970; Silvertown, 1982). Most plant communities are longer-lived than their constituent individual plants. When an individual dies, it may or may not be replaced by an individual of the same species. The replacement process ultimately occurs during the regeneration phase of the plant life cycle. Changes that favor host seedling establishment would increase host density in the community. Higher host densities increase the availability of new host tissue suitable for infection and facilitates the spread of disease (Burdon, 1982). Since host density is a function of the number of successfully established seedlings, factors that enhance seedling survival, perhaps woody litter, ultimately benefit the parasite. 
The extent to which synergistic interactions between host and parasite contribute to potentially mutual advantages changes in community structure (such as the abundance of woody litter) is speculative. However, mistletoe genotypes that cause symptomatic changes in their host that improve the chance for successful host establishment should be favored by selection as they leave a greater number of offspring. 
SECTION B

AFFECTS UPON HOST REPRODUCTION 


\section{INTRODUCTION}

Past research concerning the effects of dwarf mistletoe on cone and seed production of western United states pine species focused primarily on Jeffrey Pine (Pinus jeffreyi Grev. and Bulf.) and Ponderosa Pine (Pinus ponderosa Laws.). Pearson (1912) reported that Ponderosa pine infected with dwarf mistletoe produced 838 fewer seeds than healthy trees, whereas infected Jeffrey pines produced 1.5 times as many seeds per pound as healthy trees, indicating smaller size (Munns, 1919). Little is known concerning the effects of infection on sed production of lodgepole pine. Schaffer et al. (1983) found that in Rocky Mountain lodgepole pine, seed size but not seed number varied inversely with the level of infection.

Reductions in seed number and/or size can have detrimental effects on the intrinsic growth rate of plant populations (Silvertown, 1982). Fewer seeds can reduce the probability of deposition at safe-sites and smaller seed size reduces seedling survival (Harper, 1977). To determine the effect of Arceuthobium americanum on the reproductive capacity of Pinus contorta var. murrayana, I compared a number of reproductive characteristics among trees with different levels of infection. These included the number and size of 
cones and seeds produced, seed viability, caloric content of seeds, pollen production, and host vigor.

\section{MATERIALS AND METHODS}

\section{Cone and seed Production}

Pine trees within the same geographic region are usually synchronized in their production of cones (Schopmeyer, 1974). Good weather is needed a year before cone ripening, so climatic influences such as drought can synchronize the cone production of trees in an area into a production cycle (Fowells, 1965). The trees at the study site were synchronized in their cone production which allowed comparison of cone and seed production in trees with different levels of infection.

In the fall of 1983 and 1984, I randomly selected and felled fifteen uninfected, fifteen moderately infected, and twenty heavily infected mature lodgepole pine trees. The current year's crop of cones was harvested, counted, and returned to the laboratory where they were opened by air drying in a cone drying cabinet. The length of individual cones were subsequently measured with hand calipers. The seeds were extracted by shaking the cones in a box. Seed wings and chaff were separated from the seed by gently rubbing seeds between the hands followed by blowing a soft current of air through the seed-chaff mixture on a slightly inclined surface (Schopmeyer, 1974). Seed collected in 
1983 was pooled according to infection level. Seed data pertaining to individual trees was not available. In 1984, however, a seed count for individual trees was conducted. The seed from both years was stored in small vials at approximately $4^{\circ} \mathrm{C}$ in a refrigerator.

Seed Viability, size, and Caloric count.

I obtained random samples for seed viability tests by continually halving a pile of seeds until the desired sample size (20-25) was achieved. In 1983, I halved a pile of all seeds collected from trees of a given infection level to obtain 48 samples each from both uninfected and moderately infected trees and 62 from heavily infected trees. Seed samples were similarly obtained in 1984, except identity with individual trees was preserved. Three samples from each tree were obtained to yield a total of 45 from uninfected, 45 from moderately infected, and 60 from heavily infected trees.

I subjected the seeds to a pregermination treatment. This consisted of soaking the seed samples in $0.18 \% \mathrm{NaOCl}$ (a fungicide disinfectant) for three minutes, followed by 24 hrs. of soaking in $400 \mathrm{ml}$ of distilled water. The moist seeds were then placed in plastic bags, then into a refrigerator at about $4^{\circ} \mathrm{C}$ for thirty days (schopmeyer, 1974). Afterwards, the seeds of each sample were distributed on moistened filter paper in petri dishes and placed in a 
growth chamber set for 14 hrs. of light at $21^{\circ} \mathrm{C}$ and 10 hrs. of dark at $13^{\circ} \mathrm{C}$. The filter paper was kept moist for thirty days. The number of seeds that germinated in each sample was recorded.

A reduction in size and/or alteration of caloric content of seeds can effect seed germination and seedling establishment (Cook, 1980; Kozlowski, 1972). I based seed size on mass (mg). Random samples of seeds, ranging between 50 and 80 seeds each, were obtained from the 1983 seed collection by the method described for the seed viability test. Sixteen samples each from both the uninfected and moderately infected seed collections and 24 samples from the heavily infected collection were used. All of the seeds from each tree were used as samples for the 1984 collection. The sample mass and number of seeds in each sample were used to calculate an average seed mass for trees of each infection level.

I measured the caloric content of seeds with a Parr oxygen bomb calorimeter. Seed samples of approximately one gram were obtained as previously described for the seed viability test. Eight samples from trees of each infection level were chosen from the 1983 seed collection. A single sample from each tree was chosen from the 1984 seed collection. I recorded the number and mass of seeds in each sample so that total energy per seed and per gram could be calculated. 


\section{Pollen Production}

A measure of pollen production (in addition to seed and cone production) gives a more complete estimate of the effect dwarf mistletoe has on the reproductive effort of the host. I obtained an estimate of the amount of pollen produced at two random points within each one-hectare plot using the method of Hoekstra (1965). At each point, 4 microscope slides coated with petroleum jelly were placed approximately $3 \mathrm{dm}$ above the ground on a stake. The slides were oriented at 45 degrees along the short axis and parallel to the ground along the long axis, one slide pointing to the north, one to the south, one to the east, and one to the west. The slides were collected and replaced with new slides periodically throughout the period when pollen was shed.

I examined and counted the pollen by compound microscope using a grid having 5 squares per centimeter. Pairs of random numbers referring to a row and column on the grid were used to orient the slide and all the lodgepole pine pollen in the field of view was counted. Five random locations on each slide were counted and averaged for an estimate of pollen deposition per square millimeter of slide surface. This procedure provides a good indication of local pollen production because of the relatively short dispersal distance of pine pollen (Eranklin, 1981). 
Host Vigor

A reduction in the number and/or size of cones and seeds can be the result of reduced tree vigor (Kramer, 1960). I define vigor as the ability to assimilate light, water, and minerals, and to convert them into plant tissue. I used age, d.b.h., and bole (stem) volume as indicators of host vigor. The age, total height, and diameter measurements at $3.6 \mathrm{~m}$ intervals along the bole were taken from each of the 100 trees felled in 1983 and 1984. Bole volume for each tree was calculated using the Newton and Huber formulas for volume (Husch, 1982).

I estimated the rate of diameter growth, for the two year period before cone collection, at stump height on the bole of each tree. The thickness of each growth ring was measured to the nearest $0.01 \mathrm{~mm}$ by a recording digital micrometer (a description of this device is given in Appendix B).

Statistical Analysis

I used One-Way ANOVA and SCHEFFE's test for unequal sample size to test the variation among plots with different levels of infection. Data tested involved:

1. number of cones and seeds;

2. seed viability;

3. seed mass (mg) and caloric content (calories); 
4. number of pollen grains (per $\mathrm{mm}^{2}$ of slide surface );

5. bole volume $\left(\mathrm{m}^{3}\right)$;

6. D.B.H. (cm); and,

7. growth ring diameter ( $\mathrm{mm})$. Probability data was transformed to arcsines before being subjected to statistical analysis (Sokal and Rohlf, 1969).

\section{RESULTS}

\section{Cone and seed Production}

Heavily infected trees have reduced cone production. By averaging the cones from all trees downed in 1983 and 1984, I obtained a mean of 83 cones per tree. In 1983, the percentage of trees with cone production above the average was: 40,50 , and 5 for uninfected, moderately infected, and heavily infected trees respectively. In 1984, the percent above the average increased to 60,60 , and 45 respectively. Only 258 of the heavily infected trees sampled during the two year period produced the average number of cones, as compared to 508 of the uninfected trees. The number of cones an adult lodgepole pine tree produces each year varies, however, the variation appears to be greater in heavily infected trees. In 1983, the average cone production of heavily infected trees was significantly smaller than uninfected or moderately infected trees (Table VI). In 1984, the average cone production was similar 

MEAN SAMPLE RESULTS WITH STANDARD ERRORS FOR CONE AND SEED PRODUCTION IN 1983 AND 1984 FOR TREES WITH DIFFERENT LEVELS OF INFECTION

\begin{tabular}{|c|c|c|}
\hline Infection Level & 1983 & 1984 \\
\hline & \multicolumn{2}{|c|}{ No. of Cones Per Tree } \\
\hline Uninfected & $80+\frac{22.85^{a}}{(n=15)}$ & $113 \pm 18.16^{a}$ \\
\hline Medium & $94 \pm 17.76^{\mathrm{a}}$ & $97 \frac{f}{\left(n-19.53^{a}\right.}$ \\
\hline Heavy & 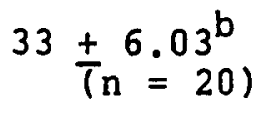 & 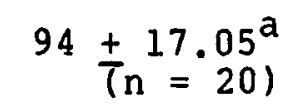 \\
\hline
\end{tabular}

\begin{tabular}{|c|c|c|}
\hline & \multicolumn{2}{|c|}{ No. of seeds Per Tree ${ }^{2}$} \\
\hline Uninfected & 2979 & $\begin{array}{c}4240 \pm 702.24^{a} \\
\left(\frac{n}{n}=15\right)^{a}\end{array}$ \\
\hline Medium & 2944 & $\begin{array}{c}4156 \pm 919.73^{a} \\
\left(\frac{n}{n}=15\right)^{a}\end{array}$ \\
\hline Heavy & 977 & $\begin{array}{c}3669 \pm\left(\frac{757}{n}=20^{23^{a}}\right. \\
.\end{array}$ \\
\hline
\end{tabular}

${ }^{1}$ Within a column pertaining to a particular measurement any pair of mean values that do not have the same letter in common are significantly different, $(p<0.05)$.

${ }^{2}$ In 1983, the total number of seeds for a given infection level was divided by the number of trees for a given infection level to give the number of seeds per tree. 
among trees with different levels of infection (Table VI). The cone production of heavily infected trees between 1983 and 1984 was significantly different.

Seed production per tree in 1983 declined with the level of infection (Table VI). I attribute this to a decline in the number of seeds per cone, which could be a consequence of reduced cone length (Table VII). In 1984, mean seed production was similar among trees with different levels of infection (Table VI).

Seed Viability, size, and Caloric Content

Dwarf mistletoe had no apparent deleterious effects on the viability of lodgepole seed. In 1983, seeds from heavi$1 y$ infected trees had significantly higher mean viability than seeds from uninfected trees (Table VIII). In 1984, seeds from trees with different levels of infection had similar viability (Table VIII).

In 1983 , the mean mass (mg) of individual seeds from moderately and heavily infected trees was significantly less than seeds from uninfected trees (Table VIII). The mean number of calories per seed was also significantly less (Table IX). In 1984, seed mass and calories per seed was similar among trees with different levels of infection (Tables VIII and IX). The mean calories per gram of seed tissue, however, did not reflect the reductions in seed 
TABLE VII

\section{MEAN SAMPLE RESULTS WITH STANDARD ERRORS FOR CONES COLLECTED IN 1983 AND 1984 FROM TREES WITH DIFFERENT LEVELS OF INFECTION}

\section{Uninfected}

Infection Leve1

Medium

Heavy

$$
\begin{array}{lr}
\frac{1983}{\text { No. of Seeds Per Cone }} & \frac{1984}{2} \\
38 & 39 \pm 2.17^{\mathrm{a}} \\
\left(\frac{1}{\mathrm{n}}=15\right) & 43 \pm 4.07^{\mathrm{a}} \\
32 & \left(\frac{1}{\mathrm{n}}=15\right) \\
30 & 40 \pm 2.32^{\mathrm{a}} \\
& \left(\frac{ \pm}{\mathrm{n}}=20\right)
\end{array}
$$

\begin{tabular}{|c|c|c|}
\hline Uninfected & $\begin{array}{l}37.0 \pm 0.15^{a} \\
(n=1193)\end{array}$ & $\begin{array}{r}36.1 \pm 0.88^{a} \\
\left(\frac{n}{n}=15\right)\end{array}$ \\
\hline Medium & $35.3 \pm 0.13^{b}$ & $37.4 \pm 1.23^{a}$ \\
\hline Heavy & $\begin{array}{r}33.7 \pm 0.20^{b} \\
(n \equiv 651)\end{array}$ & $35.4 \pm 0.85^{a}$ \\
\hline
\end{tabular}

Cone Length $(\mathrm{mm})$

${ }^{1}$ Within a column pertaining to a particular measurement any pair of mean values that do not have the same letter in common are significantly different, $(p<0.05)$.

2 In 1983, the total number of seeds for a given infection level was divided by the number of cones. In 1984, the total number of seeds per tree was divided by the total number of cones per tree. 
MEAN SAMPLE RESULTS WITH STANDARD ERRORS FOR SEEDS COLLECTED IN 1983 AND 1984 FROM TREES WITH DIFFERENT LEVELS OF INFECTION

Infection Level

$\underline{1983}$ $\underline{1984}$

\section{Probability of Seed Germination}

Uninfected

$0.63 \pm 0.02^{a}$
$(n=60)$

$0.86 \pm 0.04^{a}$

Medium

$0.73 \pm 0.02^{a b}$
$(n=60)$

$0.82 \pm 0.06^{a}$

Heavy

$0.74 \pm 0.03^{b}$

$0.87 \pm 0.01^{a}$
$(n=57)$

Seed Wt. (mg/seed)
Uninfected
$4.1 \pm 0.07^{a}$
$4.6 \pm 0.30^{a}$
Uninfect
Medium
$3.5 \pm\left(\frac{0.08^{b}}{n}=16\right)$
$4.7 \pm 0.30^{a}$
Heavy
$3.3 \pm 0.12^{b}$
$(\bar{n}=16)$
$4.2+0.21^{\mathrm{a}}$

$1_{\text {Within a column pertaining to a particular measure- }}$ ment, any pair of mean values that do not have at least one common letter are significantly different, $(p<0.05)$. 
TABLE IX

MEAN SAMPLE RESULTS WITH STANDARD ERRORS FOR CALORIC CONTENT OF SEEDS IN 1983 AND 1984 FROM TREES WITH DIFFERENT LEVELS OF INFECTION ${ }^{1}$

Infection Level

1983

$\underline{1984}$

Calories per Gram of Seed Tissue

Uninfected

$6467.3 \pm 50.65^{a}$

$6157.9+43.82^{a}$

( $\mathrm{n} \equiv 6)$

$(\mathrm{n}=\overline{\mathrm{I}} 5)$

Medium

$6451.4 \pm 41.45^{a}$

( $\mathrm{n} \equiv 6$ )

$6223.8 \pm 51.44^{\mathrm{a}}$

$(\mathrm{n}=\overline{\mathrm{I}} 0)$

Heavy

$6547.7 \pm 21.48^{a}$

$(\mathrm{n} \equiv 6)$

$6104.0+28.75^{a}$

$(n=\overline{1} 9)$

\section{Calories Per seed}

Uninfected

$22.0 \pm 0.15^{a}$
$(n=6)$

$28.57 \pm \frac{1}{\left(n=14^{a}\right.}$

Medium

$18.2 \pm 0.22^{b}$
$(n-6)^{b}$

$30.59 \pm 1.87^{2}$

Heavy

$19.0 \pm 0.38^{\mathrm{b}}$

$27.61 \pm 1.24^{2}$

$(n=-19)$

${ }^{1}$ Within a column pertaining to a particular measurement, any pair of mean values that do not have the same letter in common are significantly different, $(p<0.05)$. 
mass, and was similar in seed from trees with different levels of infection in 1983 and 1984 (Table IX).

\section{Pollen Production}

The timing of pollen release from cones did not vary significantly among one-hectare plots with different levels of infection. The same relative proportions of pollen were deposited within the same sample periods during 1984 (Table $x$ ) The daily deposition rate (ave. no. of pollen per $\mathrm{mm}^{2}$ per day), however, decreased with the level of infection within plots (Table XI). As a result, heavily infected plots had significantly lower seasonal production (Table XI).

Host Vigor

The mean age of trees increased with the level of infection (Table XII). The mean d.b.h. (cm) and bole volume, however, declined with the level of infection (Table XII). I found no significant difference in total height among trees with different levels of infection (Table XII). Tree ring growth also indicated reduced vigor of heavily infected trees. In 1983, growth rate (width of annual growth rings) was similar in uninfected and heavily infected trees, but in 1984 growth rate was significantly reduced in heavily infected trees (Table XIII). 
TABLE X

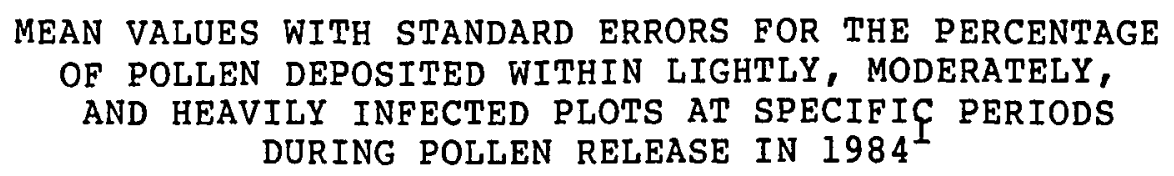

\begin{tabular}{lccc} 
Sample Periods & $\begin{array}{c}\text { Light } \\
(\mathrm{n}=5)\end{array}$ & $\begin{array}{l}\text { PERCENT } \\
\text { Medium } \\
(\mathrm{n}=5)\end{array}$ & $\begin{array}{c}\text { Heavy } \\
(\mathrm{n}=10)\end{array}$ \\
\hline $6 / 1-6 / 23$ & $6.32 \pm 0.70$ & $5.72 \pm 0.67$ & $6.64 \pm 0.41$ \\
$6 / 24-6 / 28$ & $53.35 \pm 5.26$ & $54.35 \pm 5.12$ & $52.13 \pm 2.58$ \\
$6 / 29-7 / 1$ & $22.07 \pm 4.62$ & $22.01 \pm 5.37$ & $22.20 \pm 2.18$ \\
$7 / 2-7 / 5$ & $9.15 \pm 0.40$ & $8.61 \pm 0.40$ & $9.42 \pm 0.34$ \\
$7 / 6-7 / 22$ & $6.94 \pm 0.30$ & $6.85 \pm 0.21$ & $7.82 \pm 0.35$ \\
$7 / 23-8 / 5$ & $2.15 \pm 0.34$ & $2.03 \pm 0.26$ & $1.68 \pm 0.13$ \\
Total & 100.00 & 100.00 & 100.0 \\
\hline
\end{tabular}

$1_{\text {Within a row, any pair of mean values are not }}$ significantly different, $(p<0.05)$. 
TABLE XI

MEAN VALUES WITH STANDARD ERRORS FOR POLLEN PRODUCTION IN 1984 WITHIN ONE-HECTARE PLOTS HAVING DIFFERENT LEVELS OF INFECTION

\begin{tabular}{|c|c|c|c|}
\hline Sample Periods & $\begin{array}{l}\text { Light } \\
(\mathrm{n}=10)\end{array}$ & $\begin{array}{c}\text { ollen } / \mathrm{mm}^{2} / \text { Day } \\
\text { Medium } \\
(\mathrm{n}=10)\end{array}$ & $\begin{array}{c}\text { Reavy } \\
(n=20)\end{array}$ \\
\hline $6 / 1-6 / 23$ & $3.87 \pm 0.02^{a}$ & $3.31 \pm 0.21^{\mathrm{a}}$ & $3.40 \pm 0.14^{a}$ \\
\hline $6 / 24-6 / 28$ & $35.35 \pm 4.82^{\mathrm{a}}$ & $30.28 \pm 1.53^{2}$ & $26.99 \pm 1.40^{\mathrm{a}}$ \\
\hline $6 / 29-7 / 1$ & $13.84 \pm 1.67^{\mathrm{a}}$ & $12.64 \pm 2.27^{\mathrm{a}}$ & $11.23 \pm 0.75^{\mathrm{a}}$ \\
\hline $7 / 2-7 / 5$ & $5.77 \pm 0.55^{a}$ & $4.93 \pm 0.22^{a}$ & $4.82 \pm 0.16^{\mathrm{a}}$ \\
\hline $7 / 6-7 / 22$ & $4.66 \pm 0.21^{a}$ & $3.80 \pm 0.14^{b}$ & $4.03 \pm 0.10^{a b}$ \\
\hline $7 / 23-8 / 5$ & $1.30 \pm 0.10^{a}$ & $1.20 \pm 0.14^{\mathrm{ab}}$ & $0.97 \pm 0.06^{b}$ \\
\hline $\begin{array}{l}\text { Total for } \\
\text { Season }\end{array}$ & $64.19 \pm 6.17^{\mathrm{a}}$ & $56.13 \pm 1.72^{\mathrm{ab}}$ & $51.44 \pm 1.60^{b}$ \\
\hline
\end{tabular}

\footnotetext{
${ }^{1}$ Within a row, any pair of mean values that do not have at least one common letter are significantly different, ( $p<0.05$ ).
} 
TABLE XII

MEAN SAMPLE RESULTS WITH STANDARD ERRORS FOR D.B.H. (CM), AGE (YRS.), BOLE YOLOME ( $M$ ), AND HEIGHT $(M)$ FOR FREES WITH DIFFERENT LEVELS OF INFECTION

\begin{tabular}{|c|c|c|c|c|}
\hline $\begin{array}{c}\text { Infection } \\
\text { Level }\end{array}$ & $\begin{array}{c}\text { Diameter Breast } \\
\text { Height (cm) } \\
\end{array}$ & Age (yrs.) & $\begin{array}{c}\text { Bole yolume } \\
\left(\mathrm{m}^{3}\right)^{-}\end{array}$ & Height (m) \\
\hline Uninfected & $\begin{array}{r}21.89^{a} \pm 0.58 \\
(n=28)\end{array}$ & $\begin{array}{r}98.55^{a} \\
\left(n=\frac{1.28}{29)}\right.\end{array}$ & $\begin{array}{r}0.30^{a} \pm 0.02 \\
(n \pm-28)\end{array}$ & $\begin{array}{r}15.48^{a} \\
(n=0.36\end{array}$ \\
\hline Medium & $\begin{aligned} 19.43^{b} & \pm 0.51 \\
(n & =30)\end{aligned}$ & $\begin{array}{r}106.90^{b} \\
\left(n=\frac{1.05}{31)^{5}}\right.\end{array}$ & $\begin{array}{r}0.23^{b} \pm 0.02 \\
\left(n^{-}=30\right)\end{array}$ & $\begin{aligned} 14.31^{a} & \pm 0.33 \\
(n & =30)^{3}\end{aligned}$ \\
\hline Heavy & $\begin{array}{r}19.40^{b} \pm 0.50 \\
(n \equiv 36)\end{array}$ & $\begin{array}{r}113.80^{\circ} \\
(n=2.03\end{array}$ & $\begin{array}{r}0.24^{b} \pm 0.01 \\
(n=36)\end{array}$ & $\begin{aligned} 14.66^{\mathrm{a}} & \pm 0.38 \\
(\mathrm{n} & \pm 37)^{2}\end{aligned}$ \\
\hline
\end{tabular}

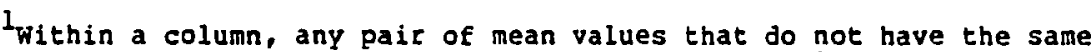
letter in common are significantly different, $(p<0.05)$. 
TABLE XIII

\section{MEAN VALUES WITH STANDARD ERRORS FOR DIAMETER GROWTH RATE (MM/YR.) IN 1983 AND 1984 FOR UNINEECTED AND HEAVILY INFECTED TREES 1}

Infection Level 1983 1984

None $(n=15)$

Heavy $(n=20)$

$$
\begin{aligned}
& 0.92 \pm 0.11^{\mathrm{a}} \\
& 0.65 \pm 0.06^{\mathrm{a}}
\end{aligned}
$$$$
1.29 \pm 0.15^{a}
$$$$
0.84 \pm 0.14^{\mathrm{b}}
$$

${ }^{1}$ Within a column, mean values with different letters are significantly different, $(p<0.05)$. 


\section{DISCUSSION}

The energetic demands of reproduction can limit cone production and cause annual variability. A heavy cone crop depletes the carbohydrate reserve of conifer trees, and foresters believe this depletion is responsible for the failure of trees to produce heavy crops each year (kramer, 1960). Several years are often required to replace the carbohydrate reserves, which contributes to irregular seed production. Depending on the species of pine, large cone crops can be expected in one, two, three or greater year cycles (Schopmeyer, 1974). Lodgepole pine can produce large cone crops in a number of consecutive years before a poor crop arises. Trees heavily infected with dwarf mistletoe apparently produce poor cone crops more frequently than uninfected or moderately infected trees, as indicated by the significant difference in cone production between 1983 and 1984. Increased variability of the annual crop implies that infection reduces the hosts' available carbohydrate reserves.

Seed production is also reduced as a consequence of heavy infection. Cones from heavily infected trees in 1983 had fewer seeds than cones from uninfected trees. Consequently, significant reductions in seed production can be 
assumed since heavily infected trees produced significantly fewer cones.

Seed reductions can result from reductions in pollen production and/or if the shedding of pollen is out of phase with the ripening of seed cones (Franklin, 1981). Pollen maturation and release from trees having different levels of infection occurred simultaneously in 1984. Its coincidence with seed cone receptiveness was not tested, but I observed no difference in seed cone maturation among plots with different levels of infection. The significant reduction in pollen production within heavily infected plots, however, may have an impact upon host seed production. Like reduced cone production, a reduction in pollen implies reduced available energy reserves.

Dwarf mistletoe apparently affects only certain aspects of lodgepole seed quality. Seeds from trees with different levels of infection had similar viabilities and calories per gram of tissue. However, individual seed mass, and consequently total calorie content, was significantly reduced.

Seed mass and/or the number of calories per seed can serve as predictors of successful germination and early survival in the field (Harper, 1977; Kozlowski, 1972). Energy stored in the megagametophytic tissue of the seed supports early root and shoot growth of seedlings. Reductions in its quantity reduces available energy to 
seedlings and hence reduces their chance to reach a selfsupporting size. Seedling survival potential, therefore, may be reduced in heavily infected stands as a result of significant reductions in the total calorie content of seeds produced by, heavily infected trees.

The reduced reproductive effort of heavily infected trees is a reflection of reduced host vigor. Heavily infected trees have reduced growth as shown by smaller mean d.b.h. and bole volume for trees of a given age. This observation supports the hypothesis that available energy is more limited for infected trees.

Since available energy reserves are partitioned between vegetative growth and reproduction (Kramer, 1960), vegetative growth can contribute to annual variability in the cone crop. In 1983, the growth rate was similar between uninfected and heavily infected trees. In 1984, cone production was similar but growth rate was significantly reduced. Vegetative growth and reproduction, apparently, are not maintained simultaneously in heavily infected trees as a consequence of reduced carbohydrate reserves.

A number of physiological explanations for shortages of available carbohydrate within infected host trees exist in the literature. Dwarf mistletoes are known to receive water, minerals, and reduced organic compounds from their host (Calder, 1983; Kuijt, 1969). High rates of respiration in the mistletoe and/or host branches (Clark and 
Bonga, 1970) could appreciably limit the availability of these nutrients to the host. Hull and Leonard (1964) found very little export of fixed-carbon compounds from infected branches (especially Witches' Broom branches), however, the import of carbon compounds into these branches was readily observed. Infected branches may function as carbon sinks as supported by Broshot's (1982) findings of significantly greater accumulations of starch in the needles from infected branches of lodgepole pine.

Reductions in host seed production can affect population growth or maintenance. Lodgepole pine reproduces only by seed, unlike many hard wood tree species that are capable of colonal expansion. Seeds from lodgepole pine are viable for less than one year. Most of the germinated seeds in a given year are from the previous year's seed crop (Fowells, 1965). A number of consecutive years with low seed production can open an avenue (unoccupied safesites) for invasion by different species or expansion by species already present. 
SECTION C

POPULATION SIZE AND AGE STRUCTURE 
INTRODUCTION

Accurate assessment of the effect that seed reductions have on population structure requires evaluation of population dynamics. Since very few seeds produce plants that reach maturity, increases in survival during any vegetative stage of the population life cycle could negate the effects of a reduced seed crop. I examined the following stages in the lodgepole population for differences (as expressed by numbers per square meter of forest floor) among lightly, moderately, and heavily infected plots:

1. Seeds produced,

2. Seeds dispersed,

3. Seeds germinating and producing small plants (hereafter called germings),

4. One year old seedlings,

5. Seedlings $2-5 \mathrm{yrs}$, of age, (no./100 $\left.\mathrm{m}^{2}\right)$,

6. Saplings 6-25 yrs. of age, (no./100 $\mathrm{m}^{2}$ ),

7. Immature trees 26-45 yrs. of age, (no./100 $\mathrm{m}^{2}$ ),

8. Mature trees 46 years of age and older (no./100

Lightly infected plots served as control stands (representing conditions expected in lodgepole stands relatively free of dwarf mistletoe) with which the moderately and heavily infected plots were compared. The potential for lightly infected and heavily infected trees to repopulate 
artificially produced clearings was also evaluated by examining seedling success in clear-cut areas adjacent to lightly and heavily infected stands.

\section{MATERIALS AND METHODS}

\section{Early Population Success}

The number of seeds produced by pine trees is closely correlated with tree size not age (Kramer, 1960; Silvertown, 1982). I assumed that the majority of lodgepole seeds produced at the site were produced by dominant trees (d.b.h. $>14.5 \mathrm{~cm}$ ). Although lodgepole pine trees can become reproductively active around ten years of age, the number of seeds they contribute to the population is negligible until they attain a mature size (Fowells, 1965). Therefore, since I knew the number of dominant trees per square meter and the number of seeds produced per dominant tree, the number of seeds produced per square meter was easily calculated.

The number of seeds that actually reached the forest floor was determined with seed traps. In 1983, I placed one seed trap (constructed with the dimensions $0.60 \mathrm{~m}$ by $0.75 \mathrm{~m}$ for easy handling in the field) on the forest floor at each of 10 random locations in each of two lightly infected and two heavily infected study plots. The following year ten additional seed traps were placed in each of two lightly infected and two heavily infected plots, giving a 
total in 1984, of 40 seed traps for each infection level. The seed traps were returned to the laboratory in late November of each year, after approximately 908 of the seeds had been dispersed (Fowells, 1965). The seeds in each trap were counted and the mean number of seeds per square meter of forest floor calculated.

I counted germlings (germinated seeds) and one year old seedlings in each of 200 randomly located quadrats in July, 1983, 1984, and 1985. There were 10 such quadrats located within each of the 20 one-hectare study plots, each quadrat having an area of one square meter. Estimates of germination success in the field was calculated as the average number of germlings per square meter relative to the average number of seeds per square meter that were collected in seed traps the previous year.

\section{Age Structure}

I sampled individuals of increasing size using various plot sizes. Seedlings greater than one year of age but less than $6 \mathrm{~cm}$ in height were sampled from the same quadrats as one year seedlings. Quadrats of $25 \mathrm{~m}^{2}$ were used to sample saplings greater than $6 \mathrm{~cm}$ but less than $2 \mathrm{~m}$ in height. Quadrats of $50 \mathrm{~m}^{2}$ were used to sample trees that were greater than $2 \mathrm{~m}$ in height but less than $16 \mathrm{~cm} \mathrm{~d} . \mathrm{b} . \mathrm{h}$. Trees larger than $16 \mathrm{~cm}$ d.b.h. were sampled from $100 \mathrm{~m}^{2}$ quadrats. 
I estimated density per unit area from the number of individuals per quadrat. Various characteristics of each individual were determined: age, d.b.h., height, rate of growth (on trees with a.b.h. $>8 \mathrm{~cm}$ only), and infection level (dwarf mistletoe rating, d.m.r.). Trees less than 8 cm d.b.h. were cut down and a slice cut from the base. A core was taken from the base of larger trees with an increment coring tool. The slices and cores were returned to the laboratory, air dried, and sanded. Tree age was determined by counting tree rings.

I used density and age determinations to compare age structure among plots with different levels of infection. A table was developed having eight age classes, each representing the number of individuals per $100 \mathrm{~m}^{2}$. One age class represented seedlings between 2 and 5 years of age, and seven 20 year age classes represented saplings and mature trees.

The area of the bole at breast height (basal area) is directly proportional to the bole biomass for most pine species, and therefore, can be used for making rough estimates of bole biomass (Curtis, 1967; Newbould, 1970; Reichle, 1981). I used total basal area, therefore, to compare total bole biomass among plots with different levels of infection. 
Regeneration in Clear-Cuts

The large number of seeds produced by lodgepole pine trees suggests a considerable potential to invade areas where mature plants are removed by fire or logging operations. Recent clear-cuts near the -study plots offered the opportunity to investigate the effect of dwarf mistletoe on actual repopulation of cleared sites from a natural seed source. The areas studied were clear-cut in 1980 (by a logging company contracted by the U.S. Forest servicel and subsequently replanted with lodgepole saplings (spaced approximately $5 \mathrm{~m}$ apart). Based on my observations, all clearcuts in the area were subjected to similar harvesting techniques.

I observed the natural repopulation of clear-cuts opposite lightly and heavily infected stands (artificially planted trees were not considered). A $100 \mathrm{~m}$ baseline transect was placed under the mature trees at the edge of a clear-cut. The infection level of stands was estimated by averaging d.m.r.'s from mature trees (d.b.h. $>14.5 \mathrm{~cm}$ ) along this transect. I sampled twenty clear-cut areas. Ten opposite stands with mean infection levels between d.m.r. classes 0 and 3.5 ( 1 ight infection) and ten between classes 3.5 and 6 (heavy infection).

Ten randomly located, $100 \mathrm{~m}$ transects were laid out perpendicular to each baseline transect ( $I$ placed the baseline so that no transect would extend more than 
half-way into a clear-cut area). On each side of each of the transects extending into a clear-cut, one meter quadrats were located at: $0,5,10,15,20,30,40,50,60$, $70,80,90$, and 100 meter intervals. The number of germlings and saplings were counted in each quadrat.

The importance of wind dispersal was considered in the sampling method. clear-cuts extending north, south, east, and west from stands with different levels of infection were equally sampled.

\section{Statistical Analysis}

I used one-way ANOVA and SCHEFFE's test for unequal sample size to test the variation among plots of different infection class. The data tested involved the number of germlings and one year old seedlings, the first year survivability, the number of individuals in each age class per $100 \mathrm{~m}^{2}$, and the number of individuals within plots. Evaluation of the number of seeds reaching the forest floor and field seed viability were made between lightly and heavily infected plots using the STUDENT-T test. Probability data was transformed to arcsines before being subjected to statistical analysis (Sokal and Rohlf, 1969). Two-way ANOVA was employed to test differences in the success of seedling spread into clear-cuts opposite lightly and heavily infected stands. 
RESULTS

\section{Early Population Success}

- The mean number of seeds (from 1983, 1984, and 1985 combined) that were produced, reached the ground, and germinated was inversely correlated with the level of infection within plots (Tables XIV and XV. The rate of seed removal from the population was similar for all plots, regardless of the level of infection, during the predispersal, dispersal, and germination periods.

First year survival (from 1984 and 1985 combined) was directly correlated with the level of infection within plots (Table XVI). As a consequence, the mean number of one year old seedlings per square meter was similar among plots with different levels of infection (Table XVI).

\section{Age Structure}

The density of young age classes increased with the level of infection within plots. The mean number of individuals per $100 \mathrm{~m}^{2}$ in age classes of 2-5 year old seedlings through 45 year old trees was directly correlated with the level of infection (Table XVII). Survival in these age classes increased with the level of infection in plots (Table XVII). A ratio of the number of observed individuals (per $100 \mathrm{~m}^{2}$ ) in heavily to lightly infected 
TABLE XIV

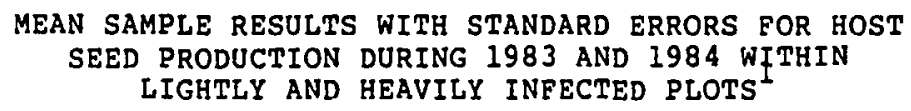

\begin{tabular}{|c|c|c|c|}
\hline $\begin{array}{c}\text { Infection } \\
\text { Level }\end{array}$ & 1983 & 1984 & $1983+1984$ \\
\hline & Per & $\begin{array}{l}\text { of Seeds Produce } \\
\text { Meter of Forest }\end{array}$ & \\
\hline Light & $\begin{aligned} 119.82 & \pm 10.23^{a} \\
n & =50\end{aligned}$ & $\begin{aligned} 170.28 & \pm 14.52^{a}\end{aligned}$ & $\begin{aligned} 145.14 & \pm 9.17^{a} \\
n & =00\end{aligned}$ \\
\hline Heavy & $\begin{aligned} 46.19 & \pm 2.43^{b} \\
n & =100\end{aligned}$ & $\begin{aligned} 173.54 & \pm 9.16^{a} \\
n & =100\end{aligned}$ & $\begin{array}{c}109.87 \\
n\end{array} 200^{142^{b}}$ \\
\hline
\end{tabular}

No. of Seeds Landing on one Sq. Meter of Forest Floor

\begin{tabular}{|c|c|c|c|}
\hline Light & $\begin{aligned} 34.63 & \pm 3.91^{\mathrm{a}} \\
\mathrm{n} & =18\end{aligned}$ & $\begin{aligned} 68.60 & \pm 3.82^{a} \\
n & \cong 40\end{aligned}$ & $\begin{aligned} 58.10 & \pm 3.55^{a}\end{aligned}$ \\
\hline Heavy & $\begin{aligned} 15.21 & \pm 2.20^{b}\end{aligned}$ & $\begin{aligned} 61.27 & \pm 5.82^{a} \\
n & \equiv 40\end{aligned}$ & $\begin{aligned} 45.98 & \pm 4.84^{b} \\
n & =60^{b}\end{aligned}$ \\
\hline
\end{tabular}

Probability of Seeds Reaching the Forest Floor

$\begin{array}{lccc}\text { Light } & 0.38 \pm 0.01^{a} & 0.46 \pm 0.03^{a} & 0.43 \pm 0.03^{a} \\ n & n=2 & n=4 & n=6 \\ \text { Heavy } & 0.34 \pm 0.04^{a} & 0.40 \pm 0.04^{a} & 0.38 \pm 0.03^{a} \\ & n=2 & n=4 . & n=6\end{array}$

$1_{\text {Within a column pertaining to a particular measurement mean }}$ values that do not have the same letter in common are significantly different, $(p<0.05)$. 
TABLE XV

MEAN SAMPLE RESULTS WITH STANDARD ERRORS FOR GERMLINGS

WITHIN PLOTS HAVING DIFFERENT LEVELS OF INFECTION BETWEEN 1983 AND $1985^{1}$

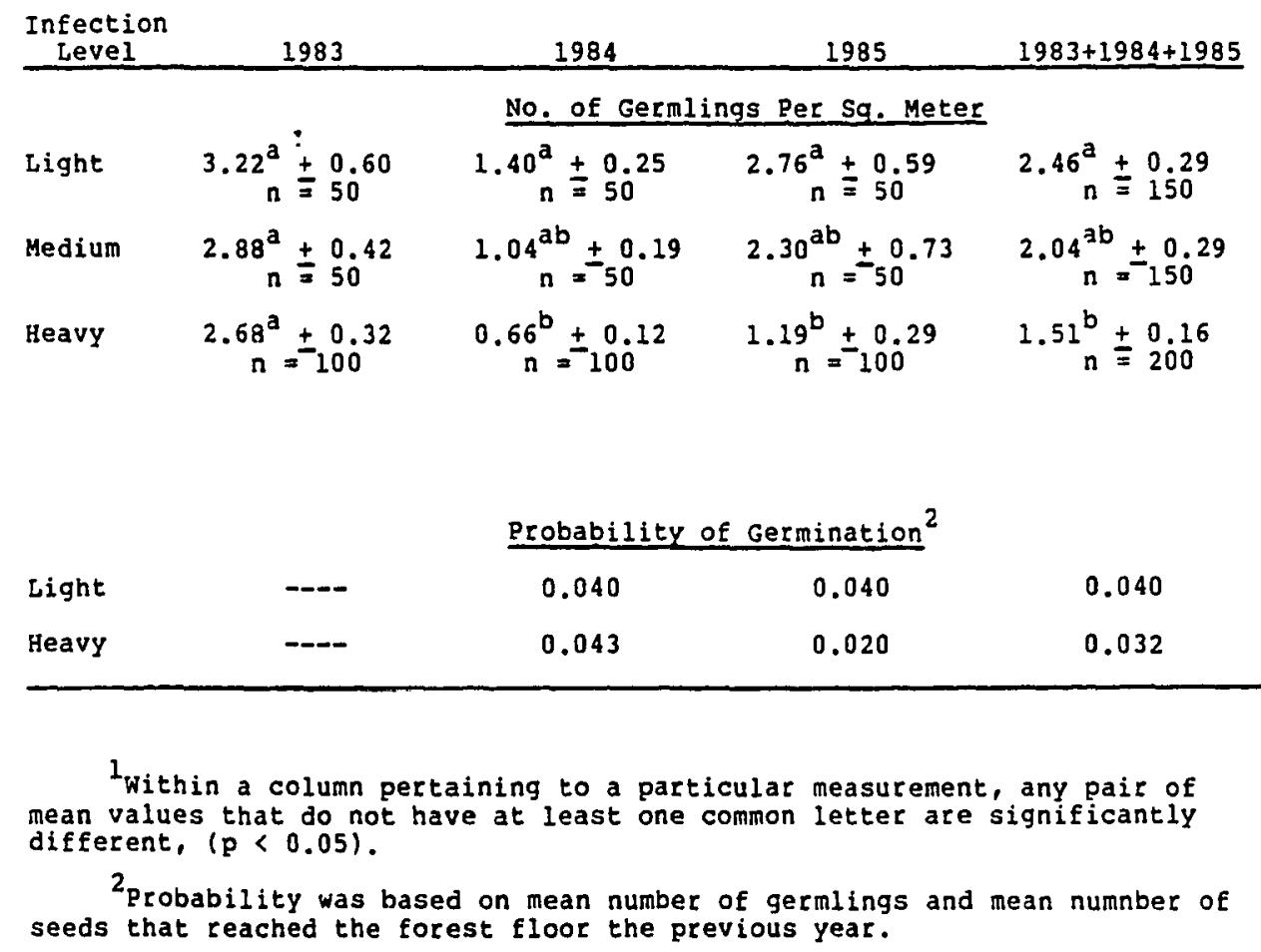


TABLE XVI

MEAN SAMPLE RESULTS WITH STANDARD ERRORS FOR FIRST YEAR SEEDLINGS IN 1984 AND 1985 WITHIN PLOTS HAVING

DIFFERENT LEVELS OF INFECTION

Infection

Level 1984 1985 $1984+1985$

No. of First Year seedlings per $\mathrm{sg}$. Meter

Light

$0.90 \pm 0.28^{a}$
$n=50$

$\begin{aligned} 0.20 \pm & 0.09^{a} \\ n & =50\end{aligned}$

$\begin{aligned} 0.55 \pm & 0.15^{\mathrm{a}} \\ \mathrm{n} & =100\end{aligned}$

Medium

$\begin{aligned} 1.18 & \pm 0.20^{a} \\ n & =50\end{aligned}$

$\begin{aligned} & 0.14 \pm 0.07^{\mathrm{a}} \\ & \mathrm{n}=50\end{aligned}$

$\begin{aligned} 0.66 \pm & \pm .12^{a} \\ n & =100\end{aligned}$

Heavy

$\begin{aligned} 1.38 & \pm 0.22^{\mathrm{a}} \\ \mathrm{n} & =100\end{aligned}$

$\begin{aligned} 0.22 & \pm 0.07^{2} \\ n & =100^{2}\end{aligned}$

0.80
$n$ $2.0^{12^{a}}$

\section{Probability of First Year Survival}
Light
$\begin{aligned} 0.30 \pm & 0.06^{a} \\ n & =38\end{aligned}$
$0.11 \pm 0.05^{a}$
$n$
$\begin{aligned} 0.21 \pm & 0.04^{\mathrm{a}} \\ \mathrm{n} & =68\end{aligned}$
Medium $\quad 0.47 \pm 0.06^{b}$
$\mathrm{n}^{-}=35$
$0.11 \pm 0.05^{\mathrm{a}}$
$n^{-}=27$
$0.32 \pm 0.05^{a}$
$n^{-}=62$
Heavy $\begin{aligned} 0.48 & \pm 0.06^{b} \\ n & =69^{b}\end{aligned}$
$\begin{aligned} 0.32 & \pm 0.06^{\mathrm{a}} \\ \mathrm{n} & \equiv 37\end{aligned}$
$\begin{aligned} 0.40 & \pm 0.04^{b} \\ n & =106\end{aligned}$

$1_{\text {Within a column pertaining to a particular measure- }}$ ment, any pair of mean values that do not have at least one common letter are significantly different, ( $p<0.05)$. 
TABLE XVII

MEAN SAMPLE RESULTS WITH STANDARD ERRORS FOR AGE CLASSES FROM PLOTS WITH DIFFERENT LEVELS

OF INFECTION

\begin{tabular}{|c|c|c|c|}
\hline Age Class & $\begin{array}{c}\text { Infection } \\
\text { Level }\end{array}$ & No. Per $100 \mathrm{sq} . \mathrm{m}$ & $\begin{array}{c}\begin{array}{c}\text { Survival } \\
\text { Rate }\end{array} \\
\end{array}$ \\
\hline 2-5 Yrs. & $\begin{array}{l}\text { Light } \\
\text { Medium } \\
\text { Heavy }\end{array}$ & $\begin{array}{l}25.00 \pm 9.60^{a} \\
41.00 \pm 11.77^{a} \\
97.00 \pm 8.37^{b}\end{array}$ & $-{ }^{3}$ \\
\hline $6-25$ Yrs. & $\begin{array}{l}\text { Light } \\
\text { Medium } \\
\text { Heavy }\end{array}$ & $\begin{array}{r}1.60 \pm 0.46^{\mathrm{a}} \\
11.76 \pm 3.38 \mathrm{a} \\
22.22 \pm 2.53^{\mathrm{b}}\end{array}$ & $\begin{array}{l}0.06 \\
0.29 \\
0.23\end{array}$ \\
\hline $26-45$ Yrs. & $\begin{array}{l}\text { Light } \\
\text { Medium } \\
\text { Heavy }\end{array}$ & $\begin{array}{r}0.28 \pm 0.21^{\mathrm{a}} \\
4.36 \pm 0.98^{\mathrm{a}} \\
15.50 \pm 3.04^{\mathrm{b}}\end{array}$ & $\begin{array}{l}0.18 \\
0.37 \\
0.70\end{array}$ \\
\hline 46-65 Yrs. & $\begin{array}{l}\text { Light } \\
\text { Medium } \\
\text { Heavy }\end{array}$ & $\begin{array}{l}0.20 \pm 0.08^{\mathrm{a}} \\
1.24 \pm 0.34 \mathrm{ab} \\
2.10 \pm 0.59^{\mathrm{b}}\end{array}$ & $\begin{array}{l}0.71 \\
0.28 \\
0.14\end{array}$ \\
\hline 66-84 Yrs. & $\begin{array}{l}\text { Light } \\
\text { Medium } \\
\text { Heavy }\end{array}$ & $\begin{array}{l}1.58 \pm 0.23^{\mathrm{a}} \\
2.14 \pm 0.37^{\mathrm{a}} \\
2.62 \pm 0.45^{\mathrm{a}}\end{array}$ & $\begin{array}{l}--- \\
---\infty \\
---\end{array}$ \\
\hline 86-105 Yrs. & $\begin{array}{l}\text { Light } \\
\text { Medium } \\
\text { Heavy }\end{array}$ & $\begin{array}{l}4.68 \pm 0.62^{a} \\
6.22 \pm 0.74^{a} \\
5.32 \pm 0.52^{a}\end{array}$ & $\begin{array}{l}--- \\
--- \\
---\end{array}$ \\
\hline 106-125 Yrs. & $\begin{array}{l}\text { Light } \\
\text { Medium } \\
\text { Heavy }\end{array}$ & $\begin{array}{l}0.44 \pm 0.12^{\mathrm{a}} \\
1.24 \pm 0.37^{\mathrm{a}} \\
1.25 \pm 0.28^{\mathrm{a}}\end{array}$ & $\begin{array}{l}--\infty \\
----\end{array}$ \\
\hline 126 Yrs. and older & $\begin{array}{l}\text { Light } \\
\text { Medium } \\
\text { Heavy }\end{array}$ & $\begin{array}{l}0.04 \pm 0.03^{\mathrm{a}} \\
0.18 \pm 0.09^{\mathrm{a}} \\
0.25 \pm 0.09^{\mathrm{a}}\end{array}$ & $\begin{array}{l}--- \\
---- \\
----\end{array}$ \\
\hline
\end{tabular}

${ }^{1}$ Within a column pertaining to an age class, any pair of mean values that do not have at least one common letter are significantly different, $(p<0.05)$.

2 The sample sizes for lightly, moderately, and heavily infected plots were 50, 50, and 100 respectively.

${ }^{3}$ Data were not collected. 
plots for each age class illustrates the difference in survival between plots of light and heavy infection (Table XVIII).

Survival rate was inversely correlated with the level of infection in plots during the 45-65 year old age class (Table XVII). Survival continued to decline with the level of infection in successively older age classes (Table XVIII). Ultimately, the density of mature tree age classes greater than 66 years was similar among plots with different levels of infection (Table XVII).

Increases in early survival alters the age distribution in moderately and heavily infected stands. Figure 2 depicts what proportion of the entire stand each age class greater than six years of age represents. In lightly infected stands, age classes between 6 and 45 years represent approximately 218 of the total density. These age classes represent about 608 and 778 of the total density in moderately and heavily infected stands, respectively (Figure 2). Total density within plots, however, did not reflect the total basal area within plots. The total number of lodgepole individuals ( $>6$ yrs.) per one-half hectare increased substantially with the level of infection (Table $X I X)$. The total basal area per one-half hectare, however, was uniform (Table XIX).

A relatively similar total basal area was proportioned differently among size categories of individuals in plots 
TABLE XVIII

$$
\begin{gathered}
\text { RATIO OF THE NUMBER OF INDIVIDUALS PER } 100 \mathrm{M}^{2} \\
\text { IN HEAVILY INFECTED TO LIGHTLY INFECTED } \\
\text { PLOTS FOR EACH AGE CLASS }
\end{gathered}
$$

\begin{tabular}{lc} 
Age Class & Ratio (heavy/light) \\
\hline Seeds Produced & 0.72 \\
Seeds on Floor & 0.74 \\
Germlings & 0.61 \\
One Year & 1.45 \\
$2-5$ Years & 3.88 \\
$6-25$ Years & 13.89 \\
$26-45$ Years & 55.36 \\
$46-65$ Years & 10.70 \\
$66-85$ Years & 1.67 \\
86 Years + Up & 1.31
\end{tabular}



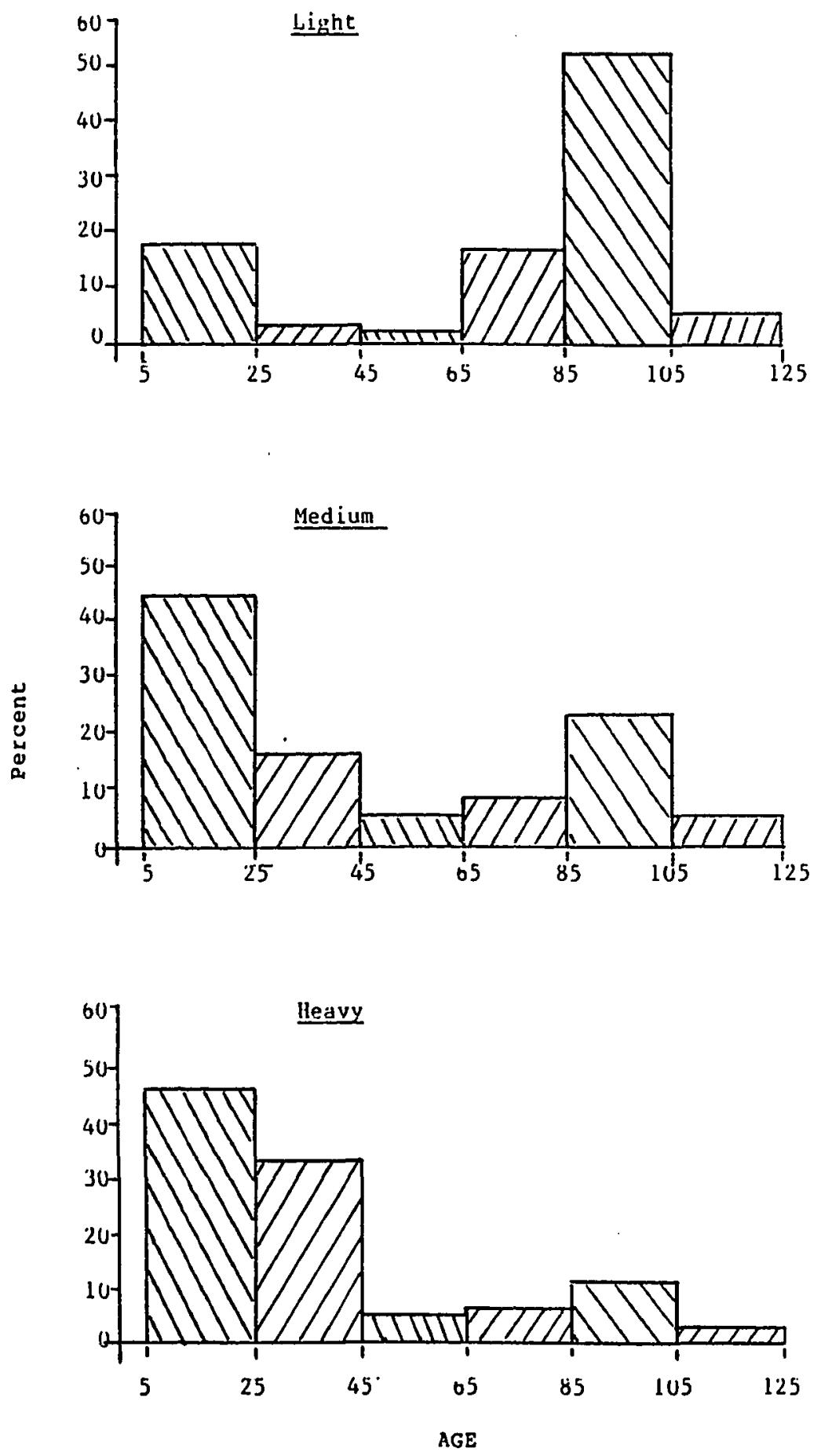

Figure 2. Age distribution for stands with different levels of infection. The percent representation by each age class greater than 6 years of age. 
TABLE XIX
TOTAL NUMBER OF INDIVIDUALS AND TOTAL BASAL AREA $\left(\mathrm{m}^{2}\right)$ PER ONE-HALF HECTARE IN PLOTS WITH DIFFERENT LEVELS OF INFECTION

\begin{tabular}{lcc}
$\begin{array}{c}\text { Infection } \\
\text { Level }\end{array}$ & $\begin{array}{r}\text { Total No. of Inqividuals } \\
\left.\text { Per } 5000 \mathrm{~m}^{2} \text { yrs. and older }\right)\end{array}$ & $\begin{array}{c}\text { Total Basal Area } \\
\text { Per } 5020 \mathrm{~m}^{\text {Area }} \\
\left(\mathrm{m}^{2}\right)\end{array}$ \\
\hline & 1691 & 10.35 \\
Light & 3450 & 10.75 \\
Medium & 7313 & 10.52 \\
Heavy & &
\end{tabular}


with different levels of infection. The total basal area represented by individuals in each $5 \mathrm{~cm}$ increment of d.b.h. up to $25 \mathrm{~cm}$ increased with the level of infection in plots (Figure 3). The total basal area represented by individuals in each $5 \mathrm{~cm}$ increment greater than $25 \mathrm{~cm}$ decreased with the level of infection (Figure 3 ).

Differences in the density of different size categories of individuals explain the observed distribution of total basal area. The mean number of seedlings, saplings, and trees with d.b.h. less than $14.5 \mathrm{~cm}$ within plots increased with the level of infection (Table $\mathrm{XX}$ ). The mean number of dominant trees (d.b.h. > $14.5 \mathrm{~cm}$ ), however, was similar among plots with different levels of infection (Table $x x$ ).

The mean d.b.h. of dominant trees in moderately and heavily infected plots was significantly smaller than trees from lightly infected plots (Table XXI). As a result, the total basal area per one-half hectare for dominant trees was 8.33 and $7.53 \mathrm{~m}^{2}$ for lightly and heavily infected plots respectively.

\section{Regeneration in Clear-Cuts}

The effects of seed reductions on regeneration were only apparent within the first $40 \mathrm{~m}$ of clear-cuts. The number of naturally occurring germlings and saplings per square meter within the first $40 \mathrm{~m}$ of clear-cuts opposite 

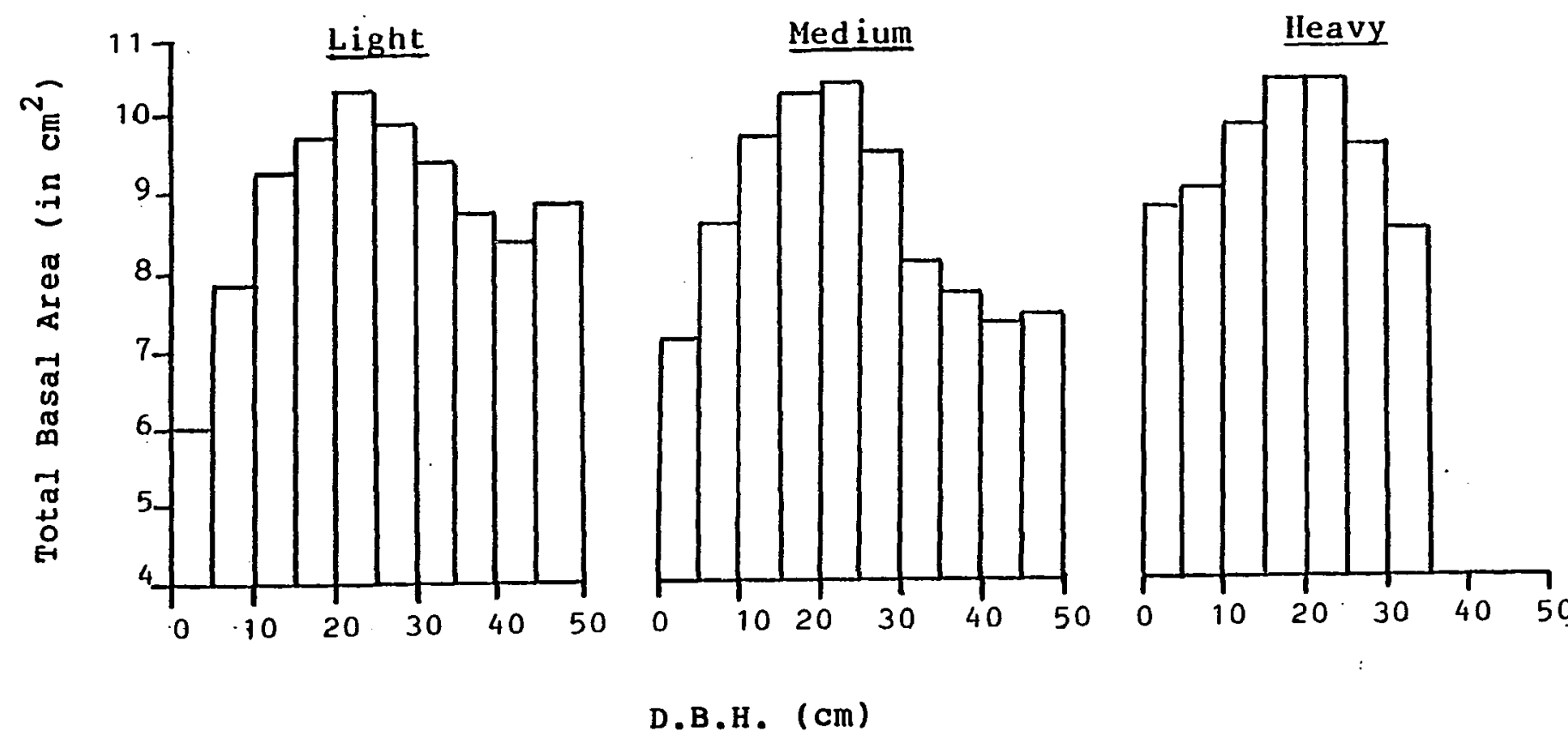

Figure 3. Natural log of the total basal area per one-half hectare represented by individuals at each increment of $5 \mathrm{~cm}$ in d.b.h. Log values allowed graphic representation on paper. 
TABLE XX

MEAN VALUES WITH STANDARD ERRORS FOR DENSITY WITHIN PLOTS HAVING DIFFERENT LEVELS OF INFECTION

\begin{tabular}{|c|c|c|c|}
\hline Plot size & Tree Size & $\begin{array}{c}\text { Infection } \\
\text { Level }\end{array}$ & No. of Plants \\
\hline One sq. Meter & $\begin{array}{l}\text { Seedlings } \\
(<6 \mathrm{~cm} \mathrm{ht.})\end{array}$ & $\begin{array}{l}\text { Light } \\
\text { Medium } \\
\text { Heavy }\end{array}$ & $\begin{array}{l}0.44 \pm 0.13^{\mathrm{a}} \mathrm{ab} \\
0.68 \pm 0.14 \mathrm{~b}^{\mathrm{b}} \\
1.41 \pm 0.30^{\mathrm{t}}\end{array}$ \\
\hline $25 \mathrm{Sq}$. Meters & $\begin{array}{l}\text { Saplings } \\
(>6 \mathrm{~cm}, \\
<2 \mathrm{~m} \text { ht.) }\end{array}$ & $\begin{array}{l}\text { Light } \\
\text { Medium } \\
\text { Heavy }\end{array}$ & $\begin{array}{l}0.54 \pm 0.15^{\mathrm{a}} \\
4.10 \pm 1.22^{\mathrm{b}} \\
9.32 \pm 1.11^{\mathrm{c}}\end{array}$ \\
\hline 50 sq. Meters & $\begin{array}{l}\text { Immature Trees } \\
\text { ( } 22 \mathrm{~m} \mathrm{ht..B} \\
\text { <16 cm d.b.h. }\end{array}$ & $\begin{array}{l}\text { Light } \\
\text { Medium } \\
\text { Heavy }\end{array}$ & $\begin{array}{l}1.70 \pm 0.25^{\mathrm{a}} \\
3.48 \pm 0.35^{\mathrm{b}} \\
4.29 \pm 0.42^{\mathrm{b}}\end{array}$ \\
\hline $100 \mathrm{sq}$. Meters & $\begin{array}{l}\text { Mature Trees } \\
(\mathrm{d} . \mathrm{b} . \mathrm{h} . \mathrm{J} \\
14.5 \mathrm{~cm})\end{array}$ & $\begin{array}{l}\text { Light } \\
\text { Medium } \\
\text { Heavy }\end{array}$ & $\begin{array}{l}4.02 \pm 0.34^{\mathrm{a}} \\
4.72 \pm 0.37^{\mathrm{a}} \\
4.73 \pm 0.25^{\mathrm{a}}\end{array}$ \\
\hline
\end{tabular}

$1_{\text {Within a column pertaining to a particular plot }}$ size, any pair of mean values that do not have at least one common leter are significantly different, $(p<0.05)$.

${ }^{2}$ sample sizes for lightly, moderately, and heavily infected plots were 50,50 , and 100 respectively. 
TABLE XXI

\section{MEAN VALUES WITH STANDARD ERRORS FOR D.B.H. OF MATURE TREES IN PLOTS WITH PIFFERENT LEVELS OF INFECTION}

Mean D.B.H. ( Cm)

$$
\begin{aligned}
& \text { Light }(n=201) \\
& \text { Medium }(n=236) \\
& \text { Heavy }(n=473)
\end{aligned}
$$

$$
\begin{aligned}
& 22.90 \pm 0.51^{a} \\
& 20.23 \pm 0.31^{b} \\
& 20.05 \pm 0.22^{b}
\end{aligned}
$$

${ }^{1}$ Any pair of mean values that do not have the same letter in common are significantly different, $(p<0.05)$. 
heavily infected stands was determined by two-way ANOVA to be significantly less than opposite lightly infected stands (Figures 4 and 5 ).

\section{DISCUSSION}

Mortality occurs during each stage in the population life cycle, thereby reducing the number of individuals in a cohort. Stand density would mirror the effects of infection on seed production (reduction in size) if there was no effect (increase) in age specific survival. My review has shown that survival rates vary between lightly and heavily infected stands.

Dwarf mistletoe reduces the number of seeds produced by its lodgepole host. As a result, the mean number of seeds produced per square meter of forest floor was reduced in heavily infected plots, and the mean number of seeds that reached the floor and germinated declined with the level of infection.

Survival of one year old seedlings was significantly higher in heavily infected plots than in lightly infected plots. This increased survival negates the effects of lower germling density (and seed production) in these same plots, as indicated by the consistent (but insignificant) increase in one year old seedling density with the level of infection. The number of safe-sites which are suitable for survival after germination apparently limits seedling 


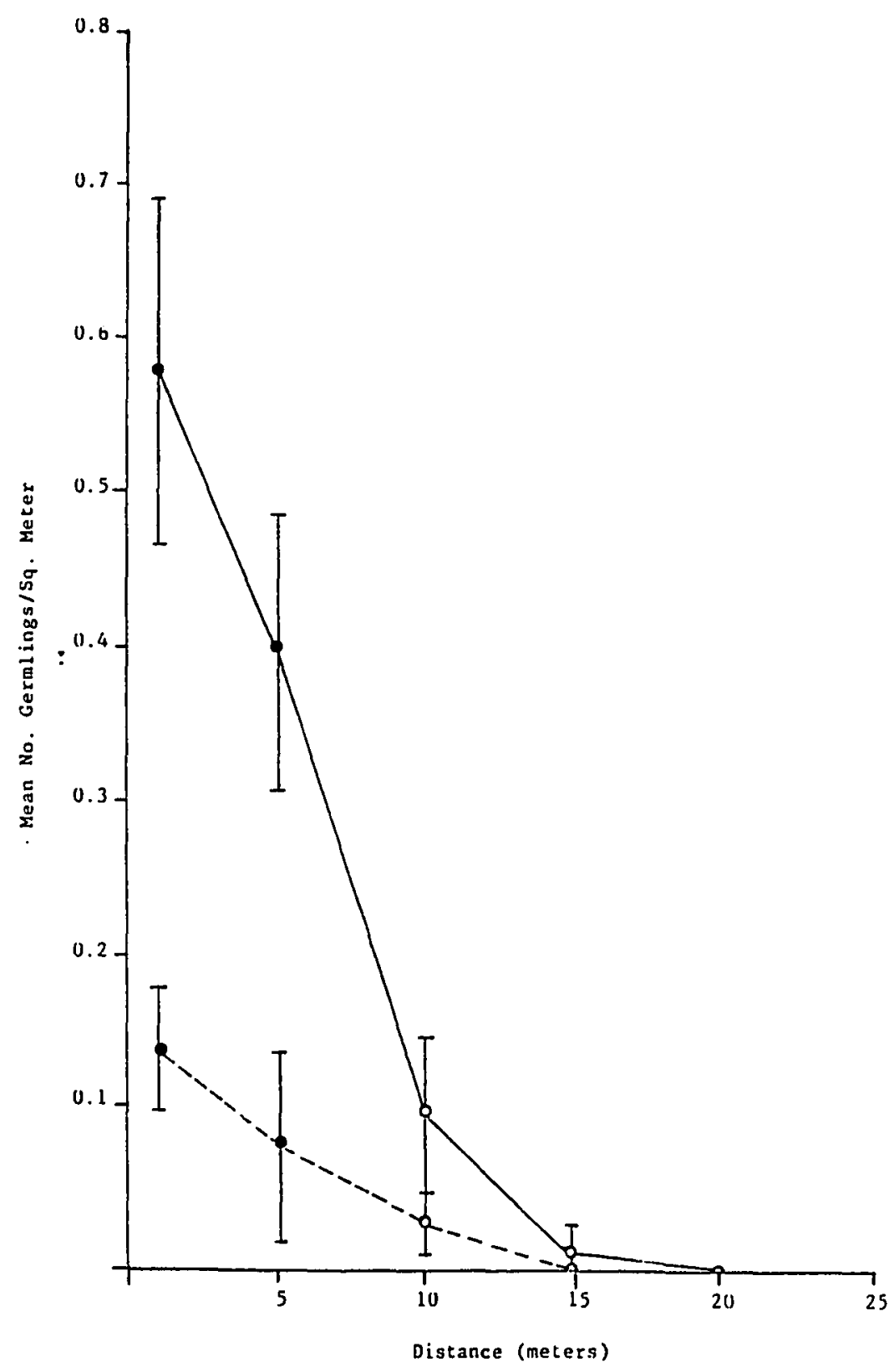

Mean no. of germlings/sq. m opposite lighty infected stands.

Mean no. of germlings/sq. m opposite heavily infected stands.

Figure 4. Mean number of germlings per square meter with standard classes clear-cuts opposite lodgepole stands with light (d.m.r. classes between $0-3$ ) and heavy (classes between $3.1-6$ ) infection (n $=80$ for both lightly and heavily infected stands).

1 circles are gignificance, mean values that are represented by shaded STUDENT-T test 


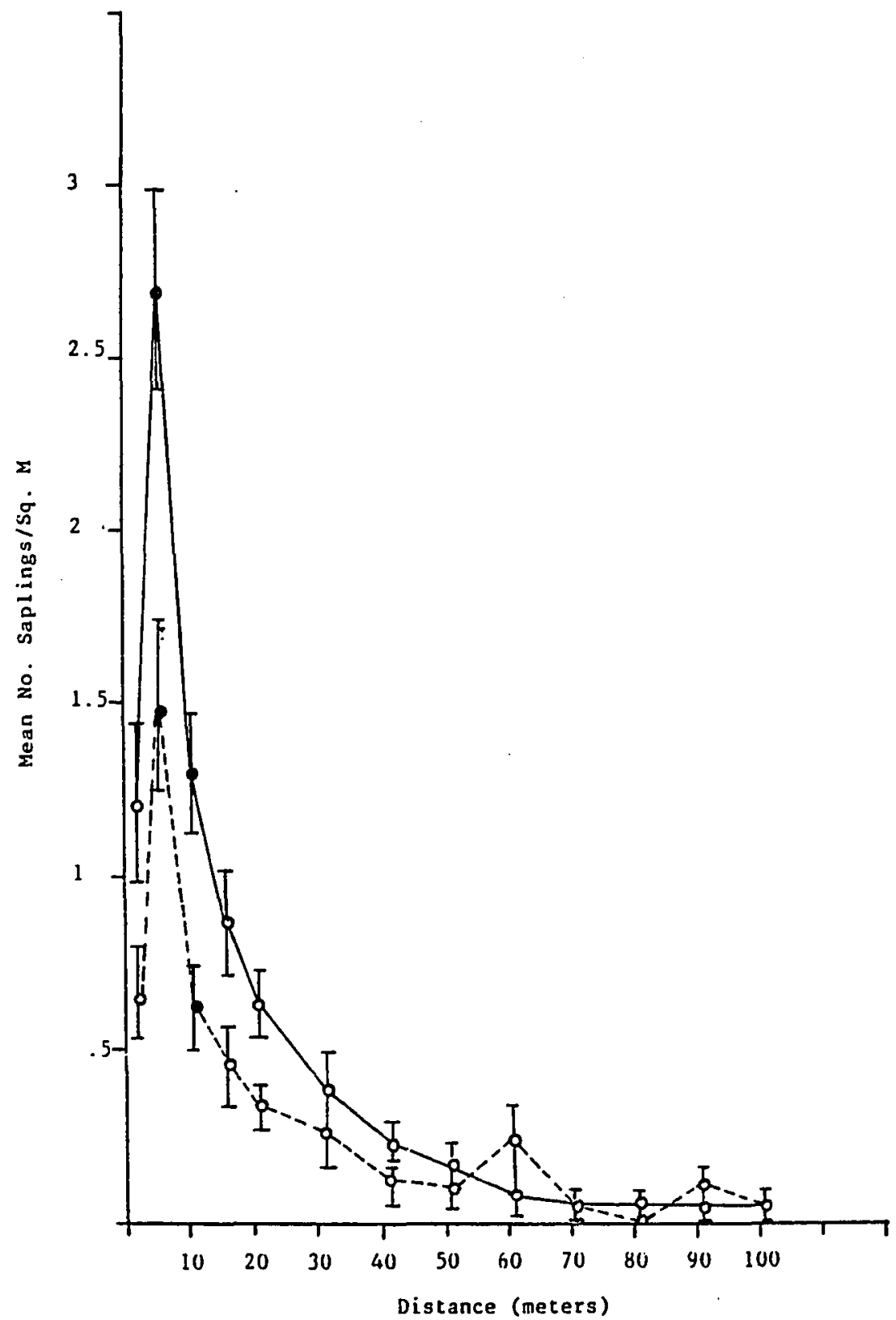

Mean no. of saplings/sq. m opposite lightly infected stands. Mean no. of saplings/sq. m opposite heavily infected stands.

Figure 5. Mean number of saplings per square meter with standard ercors in clear-cuts opposite lodgepole stands with light (d.m.r. classes between $0-3$ ) and heavy (classes between $3.1-6$ ) infection in = 80 for both lightly and heavily infected stands).

$1_{\text {At }}$ a given distance, mean values that are represented by shaded circles are significantly different, $(p<0.05)$, according to the STUDENT-T test (zar, 1984). 
density, since first year survival was not correlated with seed production.

Woody litter was also positively correlated with the level of infection as a result of increased mortality of mature trees and witches' brooms. I suggest, therefore, that woody litter contributes to the improvement of first year survival. Consequently, the number of safe-sites which are suitable for seedling survival varies directly with the abundance of woody litter, which accounts for increased seedling density with increased level of infection in plots.

Mortality during the seedling and sapling stages declined as the level of infection within plots increased. As a result, the mean density of age classes less than 45 years of age in heavily infected plots was significantly higher than in lightly infected plots. Mortality of age classes greater than 45 years, however, was directly correlated with the level of infection. Ultimately, the density of age classes greater than 66 years was similar in all plots, regardless of the level of infection.

Since the total basal area of lodgepole pine was similar within all plots, I concluded that all available resources within the study plots were being utilized. The host was resource limited. However, the different representation of basal area by different size categories of individuals indicates that resources are partitioned differently 
among seedlings, saplings, and mature trees in plots with different levels of infection. Since the soil environment was homogeneous throughout the study site, I suggest that dwarf mistletoe causes the observed differences in resource partitioning in plots with different levels of infection. Death of the host by dwarf mistletoe usually occurs only after many years of infection (Hawksworth, 1972). As a result, the presence of dwarf mistletoe primarily affects mature trees and, therefore, is the main cause for increased mortality of mature trees in heavily infected plots. Increased mortality tends to reduce the total biomass of all mature trees in moderately and heavily infected plots. Reductions in host vigor also contribute to reductions in total mature tree biomass. Although lightly and heavily infected stands had similar densities of dominant trees, a significant reduction in mean d.b.h. resulted in a reduction in their total basal area in heavily infected plots. The total resource requirement of all mature trees may, consequently, be reduced, which would result in the incomplete utilization of available resources by mature trees.

The freed resources become available to other plants, thereby leading to changes in stand structure. The primary exploiters of any unutilized resources are lodgepole seedlings and saplings, as indicated by their significant increase in density and basal area in heavily infected plots. 
Exploitation by pursha tridentata and annual species is insignificant as shown by their uniform coverage and composition throughout the study area.

The freed resources reduce intraspecific competition between saplings and mature trees which contributes to increased seedling and sapling survival in heavily infected stands. A table representing age classes shows that survival of seedlings and saplings increased with the level of infection in plots until reduced survival into the first mature tree age class (46-66 yrs.) reversed the trend. This suggests that the self-thinning process is only delayed within heavily infected plots. Intraspecific competition is probably the major factor of mortality during the 46-66 year age class. Increases in mortality during ensuing mature age classes are primarily due to infection by dwarf mistletoe.

Two environmental consequences of infection by dwarf mistletoe, therefore, offset the deleterious effects of seed reductions in lodgepole stands. First, increases in the abundance of woody litter increase the number of safesites for seedling establishment, and second, freed resources (as a result of under utilization by mature trees) reduce intraspecific competition between saplings and mature trees.

Seed reductions, however, have a substantial effect on the initial revegetation of clear-cuts. A significant 
reduction in seed production within heavily infected stands occurred in 1983, and may be assumed to account for the significant reduction in germling density within the first 20 m of clear-cuts opposite heavily infected stands in 1984. Sapling density within the first $40 \mathrm{~m}$ of clear-cuts was directly correlated with the seed production of nearby trees. This indicates that the number of safe-sites do not limit the number of seedling establishments. Consequently, the rate of revegetation is determined by the seed production of nearby trees until all available safe-sites in the clear-cut become occupied. Since the disturbance of soils and the artificial replanting of saplings were uniform, I assumed that the number of safe-sites and sapling survival were consistent in all clear-cuts.

A crop of seeds performs two major dynamic roles within plant populations: 1. maintenance of population size and 2. population expansion. Seed reductions due to infection by dwarf mistletoe appear to adversely affect only one of these roles, population expansion. However, it is questionable whether this role is significantly affected. It is very hard to demonstrate whether reductions in seed production effect mature stand density (Harper, 1977). Copious amounts of seeds always seem available for adequate seedling establishment. In undisturbed pine stands the production of seeds is normally in excess of the number of safe-site locations (Cook, 1980), therefore, a reduction in 
seed production due to infection has little impact on lodgepole population stability. For example, the mature stand density of dominant trees within lightly and heavily infected plots was 4.02 and 4.73 per $100 \mathrm{~m}^{2}$, respectively. The density of saplings at $5 \mathrm{~m}$ into clear-cuts was 280 and 155 per $100 \mathrm{~m}^{2}$, respectively. There were significantly fewer saplings in clear-cuts opposite heavily infected stands due to seed reductions from nearby trees, but will it affect mature stand density? sapling density at $5 \mathrm{~m}$ in clear-cuts opposite both lightly and heavily infected stands far exceeded the density of dominant trees in the mature stand.

Stand History

Reoccurring disturbances, such as fire or wind, do not allow pine populations to come to equilibrium (Harper, 1977). Stands are regularly returned to the regeneration phase of development. As a consequence, the age structure of stands become dominated by the cohort beginning directly after the disturbance.

The last major disturbance at the study site occurred about 120 years ago. I obtained this estimate by adding 15 years to the dominant, mature tree age class (86-105 years). Age of mature trees was determined at breast height on the bole and it takes seedlings approximately 15 years to reach this height. 
Fire scars on relatively old trees (older than 150 years) indicate that the disturbance was a forest fire. The site contained few old trees and they always occurred in heavily infected plots. Many had bole infections, indicating that infection occurred during the seedling or sapling stage. Infected relict trees could have served as sources of inoculum after the fire. Thus, the sparse distribution of old infected trees explains the patchy distribution of dwarf mistletoe at the site, and suggests that presently heavily infected stands became infected early in their development (possibly 100 to 120 years ago). Many of the mature trees in heavily infected plots had bole infections, which supports this hypothesis. 
A MODEL

Life tables provide the basis for models that predict population response to perturbing influences (Bosch, 1971; Botkin, 1972; Brussard, 1971; Buongiorno, 1980; Ek, 1979). I used the age distribution data collected for lightly and heavily infected lodgepole stands to develop a model that approximates lodgepole response to infection by dwarf mistletoe. Data in previous sections of this dissertation suggest that the present difference in age distribution of the lodgepole pine between lightly and heavily infected stands is due to the presence of dwarf mistletoe. The result of increased mortality among mature trees in heavily infected stands, and the consequential under utilization of resources, is increased seedling and sapling survival. Any disturbance that kills primarily mature trees (i.e., selective logging) frees resources. Consequently, the age distribution of lightly infected stands can change to resemble heavily infected stands if an appropriate disturbance (one that increases mature tree mortality) is introduced.

In the model, I assume that subordinate age classes replace (through increases in survival) dominant trees (those with d.b.h. > $14.5 \mathrm{~cm}$ ) according to their capacity to exploit the light, moisture, and minerals made available 
by increased mortality of the dominant trees. This capacity is primarily determined by the tree height, and crown and root volume, which are generally more developed in older individuals (Kramer, 1960). Therefore, the model replaces dominant trees first with individuals from the class of suppressed, mature trees (d.b.h. $<14.5 \mathrm{~cm}$ ), then with individuals from the 26-45 year old age class, and then from the 1-25 year old age class. In actuality, the hierarchy of resource utilization is not this simple. Trees of similar size, but different age classes, may in reality exploit unutilized resources. Nevertheless, I offer this simple hierarchy as a useful first approximation of field conditions.

The model takes the approach of the standard "Leslie Matrix" model (Table XXII). Fecundity far exceeds need, so I assume it has little effect on age distribution of stands at the site; it is not considered in the model. This view is based on the observation that an estimated 2750 and 4000 safe-sites per one-half hectare are available for seeding establishment each year in lightly and heavily infected stands respectively (Section III, Tables XIV and XVI). This compares with the mean number of seeds landing on one-half hectare of forest floor each year being 290500 and 229900 in lightly and heavily infected stands respectively. For simplicity, I initiate the model by assuming that the number of safe-sites, and consequently the size of the 1-25 
TABLE XXII

A. MATRICES FOR LIGHTLY INFECTED STANDS

B. MATRICES FOR HEAVILY INFECTED STANDS

Mature

Seedlings Saplings Trees Age Distribution

A.

$\begin{array}{rrrrrrr} & & & & & 4000 & 1-25 \text { Yrs. (Seedlings) } \\ \text { Survival } & 0.0035 & 0 & 0 & 14 & 26-45 \text { Yrs. (Saplings) } \\ \text { Survival } & 0 & 0.714 & 0.971 & 347 & 46 \text { Yrs.+ Up (Total } \\ & & & & & & \\ & & & & & & \end{array}$

B.

8850

$\begin{array}{lllll}\text { Survival } & 0.088 & 0 & 0 & 775\end{array}$

$\begin{array}{lllll}\text { Survival } & 0 & 0.138 & 0.814 & 576\end{array}$

${ }^{1}$ Each row gives age specific survival of age classes in order of age starting with seediings.

2 The number of individuals per one-half hectare in each age class. 
year age class, remain constant in all generations. In reality the number of safe-sites is directly correlated with mortality of mature trees due to increased woody 1 itter (as apparent in heavily infected stands), and therefore will increase with increase in mature tree mortality. Even so, the simplified model is satisfactory. My only concern here is to examine the consequences of increased mortality of dominant trees. This is done to simulate selective mortality, such as due to selective logging. The suppressed, mature trees continue to be affected only by natural mortality. To illustrate the function of the model, I ask what age distribution would result following a single event that caused 908 mortality (e.g., insect attack, selective logging) of the dominant trees at the study site. The resulting age structure is predicted for a time 25 years following the mortality event, the objective being to maintain a stable density of dominant trees. Beginning with the age structure and age specific survival rates listed in Table XXII (these data are based on the observed structure and rates in lightly and heavily infected stands), we first calculate an adjusted survival rate for dominant trees:

1 - natural survival rate = natural mortality rate, (natural mortality rate) + ( 8 directed mortality / $100)=$ adjusted mortality rate,

1 - adjusted mortality rate = adjusted survival rate. 
Directed and natural mortality reduce the initial number of dominant trees in lightly and heavily infected stands to 14 and 0 respectively (Figure 6). To maintain the pre-treatment density of dominant trees, 187 and 237 trees in lightly and heavily infected stands must be recruited (Figure 6). Recruits come first from the reservoir of suppressed, mature trees in the population. The number of suppressed, mature tree survivors after 25 years is 142 and 276 in lightly and heavily infected stands respectively (Figure 6). Since the density of suppressed, mature tree survivors in lightly infected stands is less than the recruits needed, all 142 trees are released from suppression (Figure 6). In heavily infected stands, 237 of the suppressed, mature tree survivors are released and 39 remain suppressed (Figure 6).

Since the pre-treatment density of dominant trees in lightly infected stands is not maintained by the total release of suppressed, mature trees (14 dominant survivors + 142 suppressed survivors < 201), recruitment from the 26-45 year age class occurs. The survival rate of the 26-45 year age class increases in proportion to the number of individuals recruited into the mature class. In this case, it increases to 1.0 because the number of recruits (46) exceeds the number of individuals (14) in the 26-45 year age class (Figure 6). 


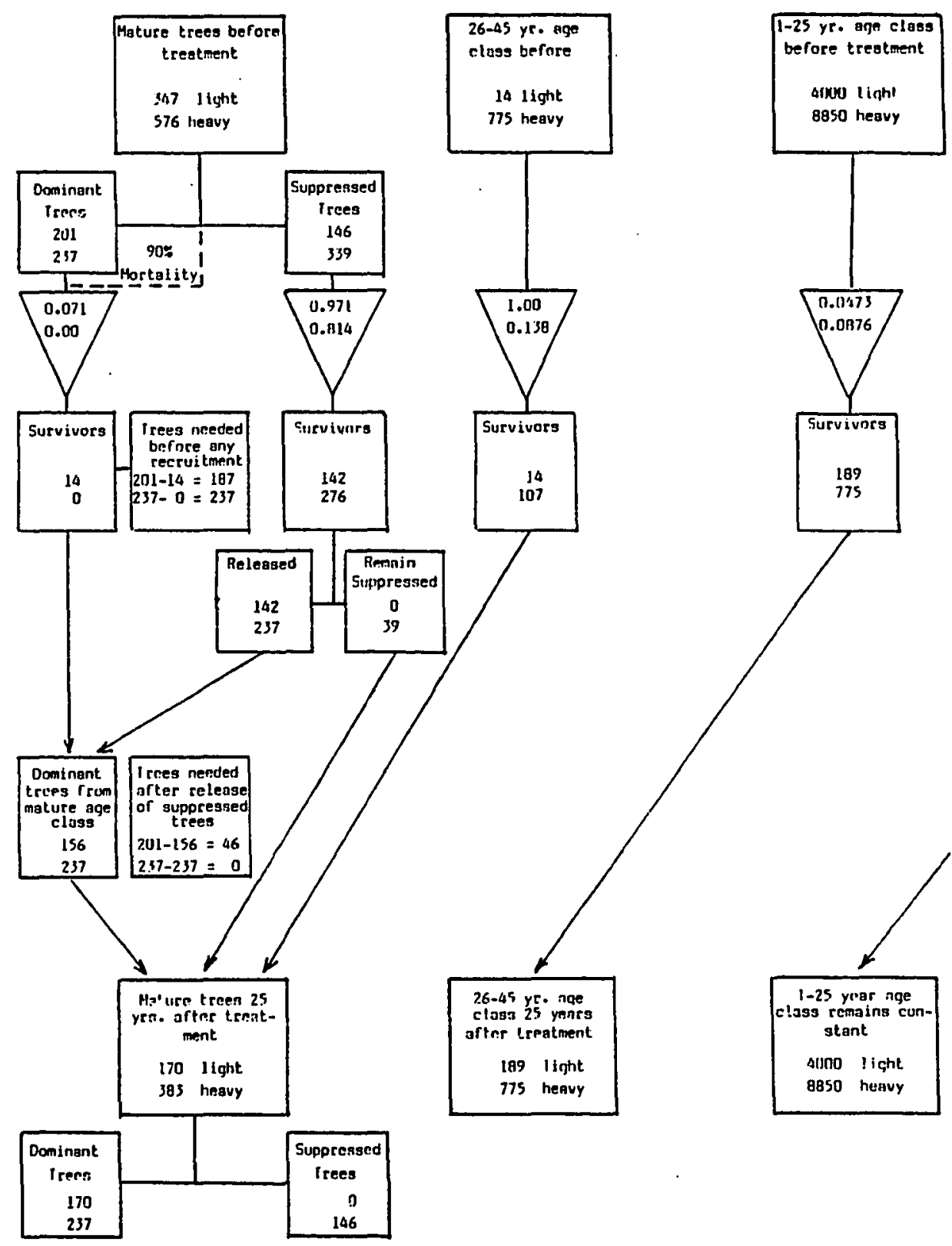

Figure 6. Schematic representation for the replacement of dominant trees by subordinate age classes after 908 directed mortality in
dominant trees.

$1_{\text {Boxes represent the number of individuals and triangles represent }}$ survival rates. The top number in both symbols represents lightly infected stands and the bottom number represents heavily infected stands. 
The number of 26-45 year age class survivors at the end of 25 years is 14 and 107 in lightly and heavily infected stands respectively (Figure 6). As a result, the size of the mature tree age class at the end of the first 25 year period is 170 and 383 in lightly and heavily infected stands respectively (Figure 6 ).

At the end of the first 25 year period, the pre-treatment density of dominant trees is not achieved in lightly infected stands. Even the unrealistic $100 \%$ release of suppressed, mature trees and 1008 survival of saplings (26-45 year age class) did not compensate for 908 directed mortality in the dominant trees. However, an increase in sapling density (survivors from the 1-26 year age class) in the first 25 years would reestablish the pre-treatment density of dominant trees within a second 25 year period (Figure 6).

Lightly infected stands respond to increased mature tree mortality with increases in sapling density. Increased seedling density (1-26 year age class) is also likely to occur in a real situation as a consequence of an increase in safe-sites (safe-sites increased with increased mature tree mortality in heavily infected plots as a result of increased woody litter), however, recall that the model assumes this variable to remain constant. The response to increased mortality of mature trees in lightly infected stands is an age structure that approximates the observed 
age structure in heavily infected stands, a response I believe due to infection by dwarf mistletoe.

\section{DISCUSSION}

Changes in host population structure can follow infection by parasites or pathogens (Burdon, 1980; Tinnin, 1984; Wicker, 1978). Pinus contorta var. marrayana, infected by Arceuthobium americanum, exemplify such a change in host population structure. In some seasons, heavily infected trees produce significantly fewer and smaller seeds than uninfected trees, indicating a diminished reproductive capacity. The proportion of seeds that germinate on the forest floor are consequently reduced. The number of seedlings surviving the first year, however, is largely determined by a number of environmental factors that define the number and quality of available safe-sites. The number of saplings and mature trees that survive is apparently determined by available resources relative to the carrying capacity of the stand.

Changes in the microenvironment which are positively correlated with an increase in seedling and sapling survival are also positively correlated with the level of infection in a stand. Significant increases in the abundance of woody litter due to increased mortality of mature trees and witches brooms is positively correlated with increased first year survival in moderately and heavily infected 
stands. I suggest that this response results from improved quality of safe-sites. Reduced vigor and increased mortality of mature trees contribute to seedling and sapling success by making available non-utilized resources. Host density increases with the level of infection in stands as a consequence of increased seedling and sapling survival. Arceuthobium americanum promotes a disturbance regime that favors regeneration of $P$. contorta. Perpetuation of the host is essential for the parasite. High densities of seedlings and saplings contribute to host persistence under normal conditions of increased mature tree mortality due to infection, and in the event of catastrophic mature tree mortality due to natural (wind and/or insect infestation) or human (selective logging) disturbances.

The concept of biotic disturbance initiating regeneration renewal is not new (White, 1979). Siccama et al. (1976) showed that vines in a connecticut woodland increased limb loss from mature trees during ice storms, thereby maintaining a patchwork of open areas which were favorable for vine establishment and growth. Strong (1977) demonstrated that heavy epiphyte load in tropical forests increase tree fall and limb loss during wind storms, thus contributing to tree renewal and maintenance of species diversity.

The negative short-term effect of parasitism (predation) of trees can have the long-term benefit of providing 
a synchronized regeneration event for the trees. Shugart (1984) sites an example of stem-boring beetles as one of the mortality synchronizing agents in the regenerative die back phenomenon of Metrosideros polymorpha ('Ohi'a) in Hawaiian landscapes. Many of the native insects of North America that are capable of mounting large-scale epidemics have, as their host, trees that do not typically produce gaps upon their death but require gaps for regeneration (e.g., p. contorta). Shugart (1984) commented that predator/prey relationships that result in synchronized mature tree mortality (thus, creating gaps) could be thought of as including a measure of mutualism when tree regeneration is considered. Pinus contorta, consequently, benefits from its coexistence with $A$. americanum because structural changes in the habitat promote host regeneration. Seed reductions resulting from infection by $A$. americanum apparently do not effect the ability of $\underline{P \text {. contorta to }}$ maintain population size. The number of seeds produced is far in excess of the number of seeds needed to sustain the population. Seed reductions, however, reduce the rate which $\underline{P}$. contorta invades clear-cuts. The number of safesites are initially in excess of the number of seeds successfully reaching the ground, therefore, sapling density increases within clear-cuts until all available safe-sites are occupied. The environment influencing seed and seedling survival is uniform within clear-cuts, thereby 
eliminating any environmental effects of infection that

offset seed reductions by increasing the number and quality of safe-sites and, thus, seedling survival. 
REFERENCES

Agrios, G.N. 1978. Plant Pathology. Academic Press. New York, San Francisco, London.

Alexander, M.E. and F.G. Hawksworth. 1975. Wild fires and dwarf mistletoe: A literature review of ecology and prescribed burning. U.S. For. Serv. Gen. Tech. Rep. RM-14. $12 \mathrm{p}$.

Alexander, R.R. 1966. Harvest cutting old-growth lodgepole pine in central rocky mountains. J. Forestry 64: $113-116$.

Anderson, R.M. 1979. The influence of parasitic infection on the dynamics of host population growth. Pp. 245281 in R.M. Anderson, B.O. Turner, and L.R. Taylor, eds., Population Dynamics. Blackwell scientific Publications. San Francisco.

- R.M. May, 1978. Regulation and stability of hostparasite population interactions, 1 . Regulatory process. Journal of Animal Ecology 47: 219-249.

Baranyay, J.A. and L. Safranyik. 1970. Effect of dwarf mistletoe on growth and mortality of lodgepole pine stands in Alberta, Can. Dept. Fish and For. Serv. Publ. 1285, 19p.

Barbour, M.G., J.H. Burk and W.D. Ditts. 1980. Terrestrial Plant Ecology. The Benjamin/Commings publishing Company, Inc.

Begon, M. and M. Mortimer. 1981. Population Ecology. A Unified study of Animals and plants. Sinauer Associates Inc., Publishers, Massachusetts.

Bosch, C.A. 1971. Redwoods: A population model. Science N.Y. 172: 345-349.

Botkin, D.B., J.F. Janak and J. Walis. 1972. Some ecological consequences of a computer model of forest growth. J. Ecology 60: 849-872.

Boyce, J.S. 1961. Forest Pathology. 3rd. edition. McGraw-Hill Book Company, Inc. New York, Toronto, London. 
Broshot, N. 1982. The effect of dwarf mistletoe (Arceuthobium americanum) upon a portion of the carbon budget of lodgepole pine (Pinus contorta). M.S. Thesis. Portland State University, Portland, Oregon.

Brower, E.J. and J.H. Zar. 1984. 2nd edition. Field and Laboratory Methods for General Ecology. Wm. C. Brown Publishers, Dubuque, Iowa.

Browning, J.A. 1974. Relevance of knowledge about natural ecosystems to development of pest management programs for agro-ecosystems. Proceedings of the Amer. Phytopathological society 1: 191-199.

Brussard, P.F., S.A. Lewin, C.N. Miller and R.H. Whittaker. 1971. Redwoods: A population model debunked. Science N.Y. 174: 435-436.

Buongiorno, J. and R.B. Michie. 1980. A matrix model of uneven-aged stands. Forest Science 26: 609-625.

Burdon, J.J. 1982. The effect of fungal pathogens on plant communities. Pp. 250-275 in E.I. Newman, ed., The plant Community as a Working Mechanism. Blackwell Scientific Publications. Oxford, London, Edinburg, Boston.

- and R.C. Shattock. 1980. Disease in plant communiEies. Applied Biology 5: 145-219.

, and G.A. Chilvers. 1982. Host density as a factor in plant disease ecology. Ann. Rev. Phytopathology 20: $143-166$.

Calder, M. and P. Bernhardt. 1983. The Biology of Mistletoes. Academic Press. Orlando, Fla.

Clark, J. and J.M. Bonga. 1970. Phatosynthesis and respiration in black spruce (Picea mariana) parasitised by eastern dwarf mistletoe (Arceuthobium pusillum). Can. J. Bot. 48: 2029-2031.

Cook, R. 1980. The biology of seeds in the soil. Pp. 107-130 in 0.T. Solbrig, ed., Evolution in Plant Populations. Blackwell scientific Publications. Oxford, London, Edinburgh.

Cullen, J.M., P.F. Kable and M. Catt. 1973. Epidemic spread of a rust imported for biological control. Nature 244: 462-464. 
Curtis, R.O. 1967. A Method of Estimation of Gross Yield of Douglas Fir. A publication of the society of American Foresters. Forest Science-Monograph 13.

Dinoor, A. and N. Eshed. 1984. The role and importance of pathogens in natural plant communities. Ann. Rev. Phytopathology 22: 443-466.

Edmonds, R.L. and P. Sollings. 1974. The impact of forest diseases on energy and nutrient cycling and succession in coniferous forest ecosystems. Proc. Am. Phytopathol. Soc. 1: 175-180.

Ek, A.R. and R.A. Monserud. 1979. Performance and comparison of stand growth models based on individual tree and diameter-class growth. Can. J. Forest Res. 9: $231-244$.

Fowells, H.A. 1965. Silvics of Forest Trees of the United States. USDA Handbook No. 271. Washington, D.C.

and G.H. Schubert. 1956. Seed crops of forest trees in the pine region of California. USDA Tech. Bull. No. 1150, 48p.

Franklin, G.E. 1981. Pollen management handbook. USDA Forest Service. Southern Forest Tree Improvement Committee. $98 \mathrm{p}$.

Gill, S.L. 1953. Broomraps, dodders, and mistletoes. Pp. 73-77 in USDA Yearbook, Plant Diseases.

Grime, J.P. 1979. Plant Strategies and Vegetation Processes. Wiley, Chichester.

Grubb, P.J. 1977. The maintenance of species-richness in plant communities: The importance of the regeneration niche. Biologi-cal Reviews 52: 107-145.

Harper, J.L. and J. White. 1970. The dynamics of plant populations. Pp. 4l-63 in P.M. denBoer and G.R. Gradwell, eds., Proceedings of the Advanced Study Institute on Dynamics of Numbers in Populations. Oosterbeek.

1977. Population Biology of Plants. Academic Press. Lon don.

Hawksworth, F.G. 1961. Dwarf mistletoe of ponderosa pine in the southwest. U.S. Forest Service Tech. Bull 1246. 112p. 
- 1961. Dwarf mistletoe brooms and other brooms in Todgepole pine. U.S. Forest Service. Rocky Mountain Forest and Range Exp. Sta. Res. Note 59, 3p.

and D. Wiens. 1972. Biology and Classification of Dwarf Mistletoes (Arceuthobium). Agricultural Handbook No. 401. USDA Forest Service. Washington, D.C.

- 1972. Dwarf mistletoes (Arceuthobium) of coniferous forests of the world. Proc. Eur. Weed Res. Counc. Symp. Parasit. Weeds, pp. 231-235.

- 1977. The 6-class dwarf mistletoe rating system. USDA Forest Service, General Technical Report RM-48.

Hoekstra, P.E. 1965. A simple, inexpensive pollen trap. USDA Forest Res. Note, SE-40. Southeast For. Exp. sta. Asheville, N.C. 2p.

Husch, B., C.I. Miller and T.W. Beers. 1982. Forest Mensuration John Wiley and Sons. New York, Chichester, Bisbane, Toronto.

Hull, R.J. and O.A. Leonard. 1964. Physiological aspects of parasitism in mistletoes (Arceuthobium and Phorodendron). The carbohydrate nutrition of mistletoes. Plant Physiology 39: 996-1007.

Johnson, F. 1952. Volume tables for lodgepole pine in oregon and Washington. USDA Forest Service. Pacific Northwest Forest and Range Experimental station.

Johnson, J.S., F.G. Hawksworth and D.D. Drummond. 1981. Yield loss of lodgepole pine stands to dwarf mistletoe in Colorado and Wyoming National Forests. Plant Disease 65: 437-438.

Kellman, M.C. 1977. The viable seed content of some forest soils in coastal British Columbia. Can. J. Bot. 48 : $1383-1385$.

Kershaw, K.A. 1973. Quantitative and Dynamic Plant Ecology. American Plant Ecology. American Elsevier PubIishing Company, Inc.

Knutson, M.D. and R. Tinnin. 1980. Dwarf mistletoe and host tree interactions in managed forests of the Pacific Northwest. USDA, Forest Service. Pacific Northwest Forest and Range Experimental station. General Technical Report, PNW-III. 
1979. How parasitic seed plants induce disease in other plants. Pp. 205-240 in J.G. Horsfall and E.B. Cowling, eds., Plant Disease, Advanced Treatise Vol. 4. Academic Press. New York, San Francisco, London.

- 1983. Physiology of mistletoe parasitism and disease responses in the host. Pp. 295-316 in $M$. Calder, ed., The Biology of Mistletoes. Academic Press. Orlando, Fla.

Kozlowski, T.T. 1972. Seed Biology. Volume 1. Academic Press. New York and London.

Kramer, P.J. and T.T. Kozlowski. 1960. Physiology of Trees. McGraw-Hill Book Company, Inc. New York, Toronto, London.

Krebs, C.J. 1985. Ecology. The Experimental Analysis of Distribution and Abundance. Harper and Row PubIishers. New York, Cambridge, Philadelphia, San Francisco.

Kuijt, J. 1955. Dwarf mistletoes. Botanical Review 21: $569-627$.

- 1969. The Biology of Parasitic Flowing Planis. University of California Press. Berkely and Los Angeles.

Lanciani, C.A. 1975. Parasite-induced alterations in host reproduction and survival. Ecology 56: 689-695.

May, R.M. 1981. Population ecology of infectious disease agents. Pp. 301-348 in R.M. May, ed., Theoretical Ecology. Sinauer Associates, Inc. Sunderland, Massachusetts.

and R.M. Anderson. 1978. Regulation and stability of host-parasite populations interactions. 2 . Destabilizing process. Journal of Animal Ecology 47: 249-268.

Munns, E.N. 1919. Effect of fertilization on the seeds of Jefferey pine. Plant World 22: 138-144.

Newbould, P.J. 1970. Methods for Estimating the Primary Production of Forests. IBP Handbook No. 2 . InternaEional Biological Programme. Blackwell Scientific Publications. Oxford and Edinburg. 
Paine, R.T. 1974. Intertidal community structure: Experimental studies on the relationship between a dominant competitor and its principal predator. Oecologia 15: 93-120.

Pearson, G.A. 1912. The influence of age and condition of the tree upon production in western yellow pine. USDA For. Serv. Circ. 196. 11p.

Pierce, W.A. 1960. Dwarf mistletoe and its effect upon the growth of Larch and Douglas Fir in Western Montana. Forest Abstracts 21: 3333.

Price, P.W. 1980. Evolutionary biology of parasites. Monographs in Population Biology 15. Princeton University Press. Princeton, Guildford. 135p.

Reichle, D.E. 1981. Dynamic Properties of Forest Ecosystems. IBP Handbook No. 23. Cambridge University Press. Cambridge, London, New York, New Rochelle, Melbourne, Sydney.

Riordon, K. 1977. Lang-term variations in trypanosome infections in highly infected tsetse flies on a cattle route in Western Nigeria. Annals of Tropical Medicine and Parasitology 71: 11-20.

Roberts, H.A. 1981. Seed banks in soils. Applied Biology $6: \quad 100-135$.

Schaffer, B., F.G. Hawksworth and W.R. Jacobe. 1983. Effects of comandra blister rust and dwarf mistletoe on cone and seed production of lodgepole pine. Plant Disease 67: 215-217.

Scharpf, R.F. and J.R. Parmeter. 1978. Proceedings of the symposium on dwarf mistletoe control through forest management. USDA General Technical Report, PSW-31.

- 1982. Population dynamics of dwarf mistletoe on Young true firs in the central Sierra Nevada, Calif. USDA Forest Service Res. Paper PSW-161, 9p.

Schmidt. R. 1978. Diseases in forest ecosystems: The importance of furitional diversity. Pp. 56-83 in J.G. Horsfall and E.B. Cowling, eds., Plant Disease, An Advanced Treatise, Vol. 2. Academic Press. New York, San Francisco, London. 
Schopmeyer, C.S. 1974. Seeds of woody plants in the United States. Agricultural Handbook No. 450. USDA Forestry Service.

Siccama, T.G., G. Weir and K. Wallace. 1976. Ice damage in mixed hardwood forest in Connecticut in relation to Vitis Infestation. Bull. Tarrey Bot. Club 103: $180-183$.

Scott, P.R. 1974. Incidence and effects of Septoria modorum on wheat cultivars. Am. Appl. Biol. 75: $321-329$.

Shugart, J. 1984. A Theory of Forest Dynamics. The Ecological Implications of Forest Succession Models. Springer-Verlag. New York, Berlin, Heidelberg, Tokyo. .

Silvertown, J.W. 1982. Introduction to Plant Population Ecology. William clowes Ltd. Beccles and London.

Smith, H.D. 1973. Observations on the cestode Eubothrium salvelini in juvenile sockeye salmon (Oncorhynchus nerka) at Babine Lake, British Columbia. Journal of the Fisheries Research Board of Canada 30: 947-964.

Smith, R.B. 1972. Relation of topography and vegetation to the occurrence of douglas-fir dwarf mistletoe at its northern limits in British Columbia. Ecology 53: 729-734.

Sokal, R.R. and J.F. Rohlf, 1969. Biometry. The Principles and Practice of statistics in Biological Research. W.H. Freeman and Company, San Francisco.

Solbrig, O.T. 1980. Demography and Evolution in Plant Populations. Blackwell scientific Publications. Oxford, London, Edinburgh.

Spurr, H. 1964. Forest Ecology. The Ronald Press Company. New York.

Strong, D.R. 1977. Epiphyte loads, tree-falls, and perennial discuption: A mechanism for maintaining higher tree species richness in the tropics without animals. J. Biogeogr. 4: 215-218.

Tinnin, R.O. and D.M. Knutson. 1980. Growth characteristics of the brooms on douglas-fir caused by Arceuthobium douglasii. Forest science 26: 149-158. 
, F.G. Hawksworth and D.M. Knutson, 1982. Witches' broom formation in conifers infected by Arceuthobium spp.: An example of Parasitic impact upon community dynamics. The American Midland Naturalist 107: $351-359$.

1984. The effect of dwarf mistletoe on forest community ecology. USDA For. Serv. General Technical Report RM-111. 131p.

Wass, E. 1976. Ecological study of shore pine stands infected with dwarf mistletoe on south eastern vancouver Island. Can. Dept. Envir. For. Serv. Pacific For. Res. Cent. Rept. BC-X-142, 33 p.

West, D.C., H.H. Shugart and D.B. Botkin. 1981. Forest Succession. Concepts and Application. Springer-Verlag. New York, Heidelberg.

Westoby, M. 1981. The place of the self-thinning rule in population dynamics. Am. Nat. 118: 581-587.

- 1984. The self-thinning rule. Pp. 105-127 in A. Macfadyen and E.D. Ford, eds., Advances in Ecological Research, Vol. 14. Academic Press. London, Orlando, San Diego, New York.

White, J. 1974. Dynamics of forest tree populations (abstr.). Bull. Can. Bot. Assoc. 7: 10-11.

and J.L. Harper. 1970. Correlated changes in plant size and number in plant populations. J. Ecology 58: $467-485$.

White, P.S. 1979. Pattern, process and natural disturbance in vegetation. Bot. Rev. 45: 229-299.

Wicker, D.E. 1978. Refinement and quantification of data for regulating dwarf mistletoe populations: An ecosystem approach. USDA For. Serv. General Technical Report PSW-31. 190p.

Williamson, M.H. 1972. The Analysis of Biological Populations. Arnold. London.

Zar, J.H. 1984. Biostatistical Analysis. Prentice-Hull, Inc. 


\section{APPENDIX A}

\section{REGRESSION ANALYSIS FOR D.B.H. as a Function of Age} Lightly Infected One-hectare Plots

$\begin{array}{lcrr}\text { Source } & \text { D.F. } & \text { SS } & \text { MS } \\ \text { Regression } & 1 & 9426.19 & 9426.19 \\ \text { Residual } & 273 & 16428.69 & 60.18 \\ \text { Total } & 274 & 25854.89 & \\ \text { equation: } \quad \mathrm{y}=-1.914+0.233 \mathrm{x} & \\ \mathrm{n}=275 & & \\ \mathrm{~F}_{2}=156.64 \text { with } & 1,273 \text { d.f.; significant at } \mathrm{p}<0.001 \\ \mathrm{r}=0.365 & \end{array}$

Heavily Infected One-hectare Plots

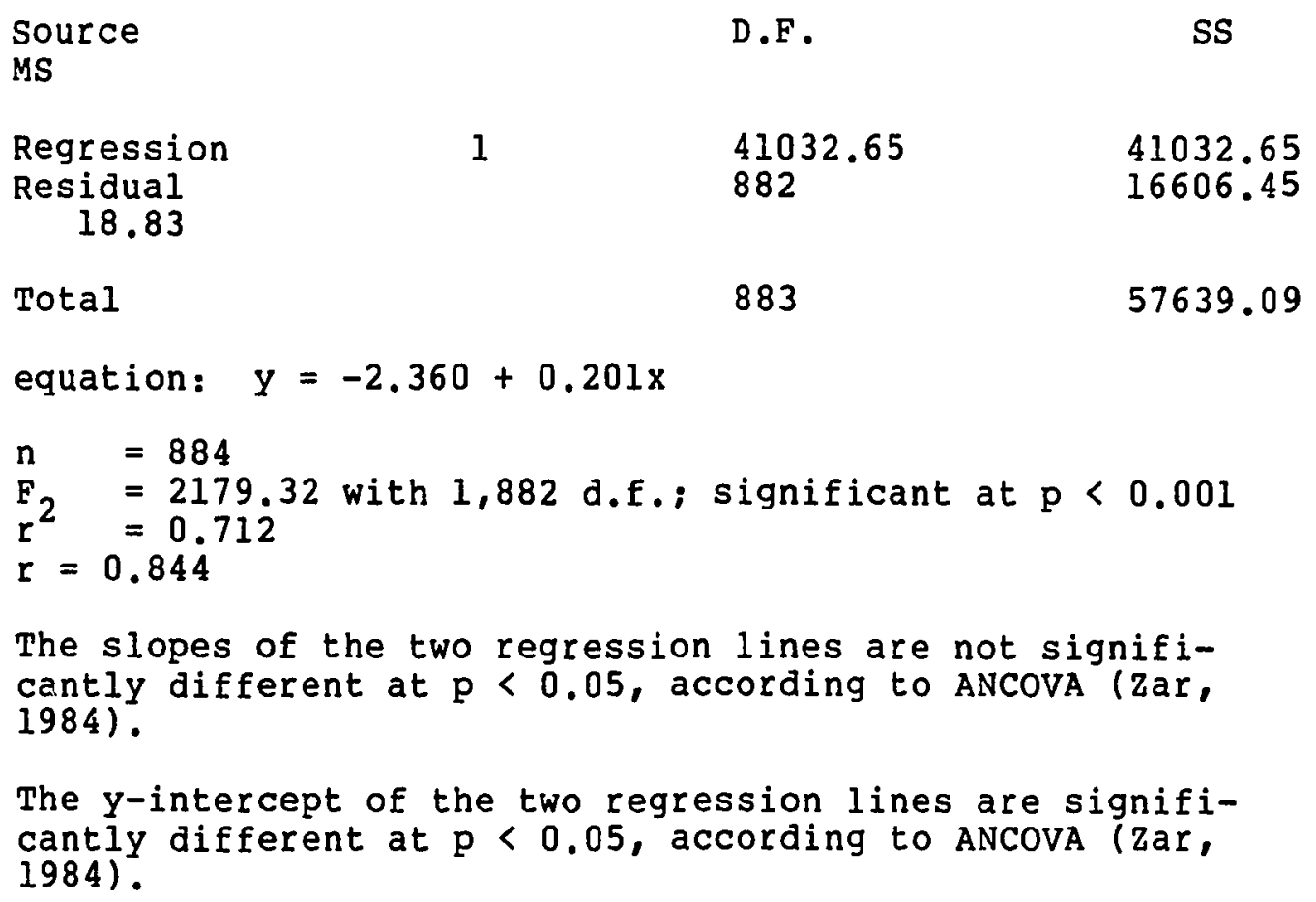




\section{APPENDIX B}

\section{DIGITAL MICROMETER}

The digital micrometer is an electronic measuring device that was designed at PSU to be interfaced with a microcomputer. A microscopic object is attached firmly by clamps to a moving stage that is driven slowly a desired distance by means of a stepper motor. The number of rotations of the lead screw can easily be converted to distance measured accurately to the nearest $n n^{-} \mathrm{mm}$ and the measurements can be displayed on the computer screen. We are indebted to Cao Minh Tuan, Garo Arakelyan, and Lee Thannum for the conception, design, and construction of this device. 